\title{
A Plant Nutrient- and Microbial Protein-Based Resistance Inducer Elicits Wheat Cultivar-Dependent Resistance Against Zymoseptoria tritici
}

\author{
M. Ors, ${ }^{1,2}$ B. Randoux, ${ }^{1}$ A. Siah, ${ }^{3}$ G. Couleaud, ${ }^{2}$ C. Maumené, ${ }^{2}$ K. Sahmer, ${ }^{4}$ P. Reignault, ${ }^{1}$ P. Halama, ${ }^{3}$ and S. Selimm ${ }^{5, \dagger}$ \\ ${ }^{1}$ Unité de Chimie Environnementale et Interactions sur le Vivant (UCEIV), Université du Littoral Côte d'Opale, CS 80699, F-62228, Calais \\ Cedex, France \\ ${ }^{2}$ Arvalis-Institut du Végétal, Station expérimentale de Boigneville, F-91720 Boigneville, France \\ ${ }^{3}$ Institut Charles Viollette (EA 7394), Institut Supérieur d'Agriculture, Université de Lille, 48 Boulevard Vauban, F-59046 Lille Cedex, France \\ ${ }^{4}$ Equipe Sols et Environnement, Laboratoire Génie Civil et géoEnvironnement (EA 4515), Institut Supérieur d'Agriculture, 48 Boulevard \\ Vauban, F-59046 Lille Cedex, France \\ 5 AGHYLE, SFR Condorcet 3417, Institut Polytechnique UniLaSalle, 19 Rue Pierre Waguet, BP 30313, F-60026 Beauvais Cedex, France
} Accepted for publication 5 July 2019.

\begin{abstract}
The induction of plant defense mechanisms by resistance inducers is an attractive and innovative alternative to reduce the use of fungicides on wheat against Zymoseptoria tritici, the responsible agent of Septoria tritici blotch (STB). Under controlled conditions, we investigated the resistance induction in three wheat cultivars with different susceptible levels to STB as a response to a treatment with a sulfur, manganese sulfate, and protein-based resistance inducer (NECTAR Céréales). While no direct antigermination effect of the product was observed in planta, more than $50 \%$ reduction of both symptoms and sporulation were recorded on the three tested cultivars. However, an impact of the wheat genotype on resistance induction was highlighted, which affects host penetration, cell colonization, and the production of cell-wall degrading enzymes by the fungus. Moreover, in the most susceptible cultivar Alixan, the product
\end{abstract}

ABSTRACT upregulated POX2, PAL, PR1, and GLUC gene expression in both noninoculated and inoculated plants and CHIT2 in noninoculated plants only. In contrast, defense responses induced in Altigo, the most resistant cultivar, seem to be more specifically mediated by the phenylpropanoid pathway in noninoculated as well as inoculated plants, since $P A L$ and $C H S$ were most specifically upregulated in this cultivar. In Premio, the moderate resistant cultivar, NECTAR Céréales elicits mainly the octadecanoid pathway, via $L O X$ and $A O S$ induction in noninoculated plants. We concluded that this complex resistance-inducing product protects wheat against $Z$. tritici by stimulating the cultivar-dependent plant defense mechanisms.

Keywords: defense mechanisms, induced resistance, manganese, wheat, Zymoseptoria tritici
Soft winter wheat (Triticum aestivum L.) is a major economically important crop in France, and Septoria tritici blotch (STB) is currently one of the most damaging foliar wheat diseases, causing yield losses reaching up to 40\% (Eyal 1999; Palmer and Skinner 2002). The infectious process of the hemibiotrophic fungus Zymoseptoria tritici, responsible for STB, is characterized by an approximately 2- to 3-week-long symptomless period. Later on, the fungus switches to a necrotrophic phase, associated with an increase of fungal biomass, the formation of pycnidia in colonized substomatal cavities, necrosis (Kema et al. 1996; Ors et al. 2017; Selim et al. 2011, 2014; Siah et al. 2010a), and the production of fungal cell-wall degrading enzymes (CWDE) (Douaiher et al. 2007a, b; Siah et al. 2010a).

At the field level, STB is mainly controlled by the use of fungicides. An alternative to chemical control is breeding for new and, if possible, fully resistant wheat cultivars. The wheat resistance against $Z$. tritici is controlled by (i) gene-for-gene relationships leading to incompatible interactions (Brading et al. 2002) and/or by (ii) nonspecific and partial resistance expressed during compatible

†Corresponding author: S. Selim; Sameh.Selim@unilasalle.fr

Funding: This research was conducted in the framework of the FSOV-SDP Septo project supported by the Groupement National Interprofessionnel des Semences et plants (GNIS), France.

*The $\boldsymbol{e}$-Xtra logo stands for "electronic extra" and indicates that one supplementary data file is published online.

The author(s) declare no conflict of interest.

(C) 2019 The American Phytopathological Society interactions (Chartrain et al. 2004a). While Z. tritici is able to overcome specific resistance controlled by 1 of the 18 known stb wheat genes (Goodwin 2007; Goodwin and Thompson 2011; Simón et al. 2012), partial resistance, controlled by several quantitative trait loci (QTL), is more durable at the field level (Orton et al. 2011).

Plant resistance is the result of an effective defense against pathogen attack. Defense responses are triggered by the recognition of molecules derived from pathogens. The first level of defense is based on the perception of pathogen-associated molecular pattern (PAMP) or microbe-associated molecular pattern, and is called PAMP-triggered immunity (PTI) (Nürnberger and Scheel 2001; Deller et al. 2011; Henry et al. 2012; Mengiste 2012). To overcome PTI, effectors have emerged in pathogens, that are released within the host during the infection process to suppress PTI (Li et al. 2013), which results in a compatible interaction associated with partial resistance, depending on the degree of effectiveness of triggered defense pathways. In turn, plant receptors can recognize such pathogen effectors, resulting in a second type of immunity referred to as effector triggered immunity (ETI), leading to an incompatible interaction (Jones and Dangl 2006; Deller et al. 2011) and total resistance.

Wheat defenses against $Z$. tritici have been studied during compatible and incompatible interactions, revealing an early induction of peroxidase (POX) activity and $\mathrm{H}_{2} \mathrm{O}_{2}$ accumulation in wheat cells, associated with wheat resistance to $Z$. tritici (Shetty et al. 2003, 2007). Different defense-related genes, such as genes encoding PR-proteins, were described as early and highly upregulated during the biotrophic phase of an incompatible interaction, while a slight induction only or a repression were observed during a compatible interaction (Adhikari et al. 2007; Ray et al. 2003; Yang et al. 2013a, b). However, by comparing 
defense-related gene expression in eight combinations of cultivars and isolates leading either to compatible or incompatible interactions, no significant difference was observed in the responses during the symptomless phase of colonization, suggesting that induction of defense gene expression is not specific to incompatible interactions (Orton et al. 2017). Moreover, a comparison between cultivars with different relative levels of susceptibility against $Z$. tritici during compatible interactions highlighted a constitutive expression of defense-associated genes at a higher level in the less susceptible studied cultivars (Ors et al. 2017). Surprisingly, during the symptomless phase of fungal development, many defense genes were induced in the most susceptible cultivar, while no induction or only slight inductions were observed in the less susceptible cultivar (Ors et al. 2017). These results underline the complexity of the mechanisms involved in specific or partial resistances of wheat against $Z$. tritici.

The induction of plant defense mechanisms by resistance inducers is an attractive and innovative alternative to reduce the use of fungicides because induced resistance is a natural and potentially effective, persistent and durable strategy (Samain et al. 2019; Walters et al. 2005, 2008). So far, a number of resistance inducers have been developed, based on either natural or synthetic compounds, that could be used in crop protection at the field (Tayeh et al. 2014; Thakur and Sohal 2013; Vavrina et al. 2004; Walters et al. 2008). Induced resistance could be related to a direct elicitation of defense responses as well as to a sensitization by a priming agent, which results in the expression of earlier and/or stronger basal defense mechanism upon a pathogen attack (Conrath et al. 2006; Walters et al. 2005).

The only resistance inducer currently registered on wheat against STB in France is Vacciplant (Goëmar, France), which contains laminarin (https://ephy.anses.fr/ppp/iodus-2-cereales/). NECTAR Céréales is currently commercialized as a complete foliar fertilizer based on sulfur $(>25 \%)$, manganese sulfate $(>2.5 \%)$, and cellulase (>0.0015\%) (https://www.agronutrition.com/). NECTAR Céréales is investigated in this work for its protective efficacy against STB and for its wheat defense activation properties. We compared the resistance induced by this product against a given $Z$. tritici strain in three distinct wheat cultivars characterized by different partial resistance levels in the field. On the one hand, the impact of the treatment on the infection process and the pathogenicity of the fungus were measured by cytological and biochemical approaches during both biotrophic and necrotrophic phases of Z. tritici. On the other hand, various defense pathways were investigated at biochemical and molecular levels during the early period following treatment with NECTAR Céréales in both inoculated and noninoculated plants. The influence of the wheat genotype on the induced resistance level will be discussed.

\section{MATERIALS AND METHODS}

Fungal inoculum preparation. Z. tritici strain T01193 (GenBank accession number KX356102), isolated from Northern France (Lorgies), is moderately resistant to sterol $14 \alpha$-demethylase inhibitor (DMI) fungicides, characterized by three single nucleotide polymorphism mutations (M-281-V, A-379-G, and I$381-\mathrm{V}$ ) in the cyp51 gene encoding for sterol $14 \alpha$-demethylase (Selim 2016). Fungal material (in vitro cirrhus) of this strain stored at $-80^{\circ} \mathrm{C}$ was activated by transfer to fresh potato dextrose agar (PDA) medium (39 $\mathrm{g} \mathrm{liter}^{-1}$; Sigma). After 7 days incubation at $18^{\circ} \mathrm{C}$, with a 12 -h photoperiod, spore suspensions were prepared by washing the cultures using sterile distilled water. Then, the concentration of spores was adjusted to the desired concentration using a Malassez cell.

Direct antifungal assays. Antifungal activity of NECTAR Céréales (sulfur $(>25 \%)$, manganese sulfate $(>2.5 \%)$, and cellulase $(>0.0015 \%)$ against $Z$. tritici (on both fungal growth and spore germination) was assessed in vitro using PDA medium amended with different concentrations of the product $(1.2,3.7,11.1,33.3$, and $100 \mathrm{ml} \mathrm{liter}^{-1}$ ), using the spotting and spore germination methods described by Siah et al. (2010b). The product was added to the medium at $30^{\circ} \mathrm{C}$ after autoclaving. The effect on fungal growth was recorded by measuring the colony perpendicular diameters after 10 days incubation at $21^{\circ} \mathrm{C}$ in the dark, while the effect on spore germination was evaluated after 1 day incubation by determining the percentage of germinated spores calculated from 100 spores under a light microscope (Nikon, Eclipse80i) for each dish (Siah et al. 2010a). Three dishes were used as replicates for each treatment, including controls, within both spotting and spore germination bioassays.

Plant growth and protection tests. Alixan, Premio, and Altigo wheat cultivars were used in this study. These cultivars exhibited various levels of partial resistance against STB under field conditions in 2009 and were noted as 4, 5.5, and 7, respectively, on a scale from 1 (highly susceptible) to 9 (highly resistant). Wheat grains were germinated in Petri dishes and wheat plantlets were grown in the greenhouse as described by Ors et al. (2017). After 3 weeks (when third leaves from the base of plants were fully expanded), plants of each pot were sprayed with $2.5 \mathrm{ml} /$ plant of a solution containing NECTAR Céréales at $8.73 \mu \mathrm{l} / \mathrm{ml}$ of distilled water. This dose of NECTAR Céréales (previously named FSOV7) was identified by Ors et al. $(2012,2013)$ as the most effective dose to protect wheat against $Z$. tritici. Control plants were treated with distilled water. Plants were inoculated $48 \mathrm{~h}$ after treatment as mentioned in Selim et al. (2014). Briefly, 21-day-old plants were inoculated by spraying a $2-\mathrm{ml} Z$. tritici inoculum $\left(2 \times 10^{6}\right.$ spores $/ \mathrm{ml}$ ) in $10 \mathrm{mM} \mathrm{MgSO}_{4}$ amended with $0.1 \%$ polyoxyethylenesorbitan monolaurate surfactant (Tween 20, Sigma). Controls were sprayed with $2 \mathrm{ml} /$ plant of the same solution without conidia. Five replications were carried out for each treatment. Plants in pots were covered with transparent polyethylene bags for 3 days and the disease was scored at 21 days after inoculation (dai) by noting the percentage of the third leaf's area covered by lesions (chlorosis and necrosis) and by noting their pycnidial density on a scale from 0 (absence of pycnidia) to 5 (high density of pycnidia) as described by Ors et al. (2017).

Histological analyses. Two-centimeter leaf segments were harvested from the third expanded wheat leaf at different time points (1, 5, and 21 dai) and observed microscopically. Spore germination and leaf penetration by $Z$. tritici was assessed using Fluorescence Brightener 28 (Calcofluor, Sigma) at a wavelength of $365 \mathrm{~nm}$ according to Siah et al. (2010a). Mesophyll colonization was investigated using Trypan blue according to Ors et al. (2017). The percentage of germinated spores (GS) was recorded at 1 dai. Total germinated spores with penetrated germ tube (PS) and within PS, penetration through stomata (PSS) were determined at 5 dai. At 21 dai, total colonized substomatal cavities (CS) among 150 randomly chosen cavities were recorded and, within CS, percentages of colonized substomatal cavities bearing pycnidia (CSP) were estimated.

Protein extraction and enzymatic assays. $C W D E$. Protease, $\beta$-1,4-endoglucanase and $\beta$-1,4-endoxylanase activities were measured according Ors et al. (2017) and total protein concentrations were determined at $595 \mathrm{~nm}$ using the method of Bradford (1976). Bovine serum albumin (Sigma A7906) was used as standard.

Plant enzyme assays. POX activity was measured according to Mitchell et al. (1994) modified by Randoux et al. (2006) and phenylalanine ammonia lyase (PAL) activity according to Randoux et al. (2010) at $0,12,24,48,54,60,72$, and $120 \mathrm{~h}$ after treatment.

RNA extraction and gene expression quantification by quantitative real-time RT-PCR. The third expanded wheat leaves were sampled at $0,12,24,48,51,54,60,72,120$, and $168 \mathrm{~h}$ after treatment. Total RNA extraction and real time RT-PCR was performed according to Ors et al. (2017) and Livak and Schmittgen (2001) to quantify the expression patterns of nine genes: PR1, CHIT2, gluc, LOX, AOS, PAL, CHS, POX2, and OXO. 
The TUB6 and GAPDH genes were used as endogenous reference for each treatment. The primers used in this study were published previously in Ors et al. (2017).

Statistical analysis. All experiments were carried out using at least three technical replications and two biological replicates. Data represent continuous variables and were analyzed using analysis of variance (Tukey's test at $P \leq 0.05$ ) assuming a normal distribution. Variances were stabilized by logarithmic transformation of data if necessary, as described by Ors et al. (2017). All data were analyzed by Xlstat software (Addinsoft, Paris, France).

\section{RESULTS}

Protection efficacy on Alixan, Premio, and Altigo inoculated with $Z$. tritici. In order to evaluate the protection efficacy of NECTAR Céréales against $Z$. tritici, the percentage of leaf area with symptoms and their pycnidial density were assessed on the third fully expended wheat leaves from the three cultivars at 21 dai (Fig. 1; Supplementary Data File S1). In the nontreated inoculated (nTI) control, the percentage of leaf area with symptoms (Fig. 1A) recorded in Alixan and Premio was not significantly different (41.7 and $42.6 \%$, respectively), but was significantly lower in Altigo (27.7\%). In plants treated with NECTAR Céréales, disease severity $(10.8,10.1$, and $2.9 \%$ in Alixan, Premio, and Altigo, respectively) was significantly lower than in their nTI controls, corresponding to reductions by $74.1,76.3$, and $89.5 \%$ on Alixan, Premio, and Altigo, respectively.

In nTI controls, the pycnidial density (Fig. 1B) recorded in Alixan was significantly higher (2.9) than in Premio (1.1) and Altigo (1.1). In plants treated with NECTAR Céréales, a significant reduction of pycnidial density was observed in Alixan, Premio, and Altigo (55.3, 66.3, and 91.3\% reductions, respectively).

Figure 2 shows the third wheat leaves harvested at 21 dai from Alixan, Premio, and Altigo nontreated and noninoculated (nTnI), nontreated inoculated with Z. tritici (nTI) and treated with NECTAR Céréales before inoculation. In each cultivar, nTI leaves exhibited chlorosis and necrosis related to disease development compared with nTnI leaves. Symptoms were drastically reduced in leaves treated with NECTAR Céréales before inoculation. Furthermore, the NECTAR Céréales-treated noninoculated leaves, especially in Altigo, displayed a lighter green color than the nTnI controls, and chlorosis at the tip (data not shown).

Alteration of the $\boldsymbol{Z}$. tritici infectious process. In order to evaluate the impact of NECTAR Céréales on the development of $Z$. tritici in the three cultivars, five cytological parameters were assessed at different time points after infection (Fig. 3). At 1 dai, more than $60 \%$ of fungal spores were germinated on the nTI controls of the three cultivars (Fig. 3A). No significant effect of NECTAR Céréales treatment on spore germination was observed (Fig. 3A). This result found in planta agrees with the in vitro antifungal assays, which showed no significant antifungal effect of NECTAR Céréales on both the growth and spore germination of Z. tritici when tested on PDA medium (data not shown).

At 5 dai, the percentage of germinated spores with penetrated germ tube (PS) recorded in Alixan, Premio, and Altigo nTI controls were not significantly different (between 39.3 and 55.9\%) (Fig. 3B). Alixan plants treated with NECTAR Céréales had a percentage of PS significantly lower than that of the nTI control (33.3\% compared with 53\% in nTI) corresponding to a reduction by $37.2 \%$ (Fig. 3B). No significant difference was detected for the percentages of penetrations through stomata (PSS) among the three nTI cultivars (between 24.2 and 28.2\%) and between NECTAR Céréales-treated plants and their nTI controls (between 15.6 and $26.2 \%$ ) (Fig. 3C).

Concerning the percentage of total colonized substomatal cavities (CS) recorded at 21dai, no significant difference in Alixan, Premio, and Altigo nTI controls was found (between 72.0 and 79.2\%). In Premio and Altigo treated with NECTAR Céréales the percentage of CS (31.4 and $27.8 \%$, respectively) was significantly lower than in their nTI controls, corresponding to reductions by 56.4 and $61.9 \%$, respectively, but not in Alixan (Fig. 3D). Likewise, in the case of CS bearing pycnidia (CSP), only Premio treated with NECTAR Céréales had a percentage significantly lower $(3.8 \%)$ than in the nTI control, corresponding to a reduction by $84.1 \%$ (Fig. 3E).

CWDE activities. The fungal $\beta$-1,4-endoxylanase, $\beta-1,4-$ endoglucanase, and protease activities were measured in leaves from Alixan, Premio, and Altigo (Tables 1, 2, and 3). At 1, 5, and 11 dai, corresponding to the biotrophic phase, all of these enzyme activities were at low levels and not significantly different from those of nTnI controls.

Later on, the $\beta$-1,4-endoxylanase activity levels recorded in Alixan and Premio nTI controls at 17 dai $\left(0.08\right.$ and 0.04 units $\mathrm{mg}^{-1}$ of total protein) were significantly higher than in their nTnI controls ( 0.03 and 0.01 units $\mathrm{mg}^{-1}$ of total protein, respectively), unlike in Altigo (between 0.02 and 0.03 units $\mathrm{mg}^{-1}$ of total protein for both nTI and nTnI) (Table 1). At this time point, enzyme activity, recorded in Alixan and Premio treated with NECTAR Céréales and inoculated, was significantly lower than in their nTI controls, without significant differences from their nTnI controls. At 21 dai, the $\beta-1,4$-endoxylanase activity was significantly higher in the three nTI cultivars than in their nTnI controls, and was significantly higher in Alixan than in Premio and Altigo. After treatment, this activity was significantly lower only in Alixan treated with NECTAR Céréales compared with its nTI control.

Similar results were recorded for $\beta$-1,4-endoglucanase activity (Table 2) at 17 and 21 dai.

For the protease, at 17 dai, NECTAR Céréales significantly reduced enzyme activity only in the nTI control of the most susceptible cultivar Alixan compared with the nTnI control (Table 3). At 21 dai, this activity reached 2.66 milli-unit $\mathrm{mg}^{-1}$ total protein in Alixan nTI plants and was significantly higher than in nTI Premio and Altigo. However, only Premio treated with NECTAR Céréales exhibited an activity significantly reduced $(0.07$ milli-unit $\mathrm{mg}^{-1}$ total protein) compared with its nTI control (Table 3).

Induction of POX and PAL activities. Total POX and PAL activities were measured in Alixan, Premio, and Altigo at 0, 24, 48, and $72 \mathrm{~h}$ after treatment with NECTAR Céréales in both infection and noninfection contexts (Figs. 4 and 5). POX activity in plants treated with NECTAR Céréales was significantly higher than in the nTnI control in Alixan (Fig. 4A) at both 48 and $72 \mathrm{~h}$, and in Premio (Fig. 4B) and Altigo (Fig. 4C) at $72 \mathrm{~h}$. In inoculated plants, the POX activity in NECTAR Céréales-treated and inoculated plants was significantly higher in Alixan at 45 and $72 \mathrm{~h}$ and in
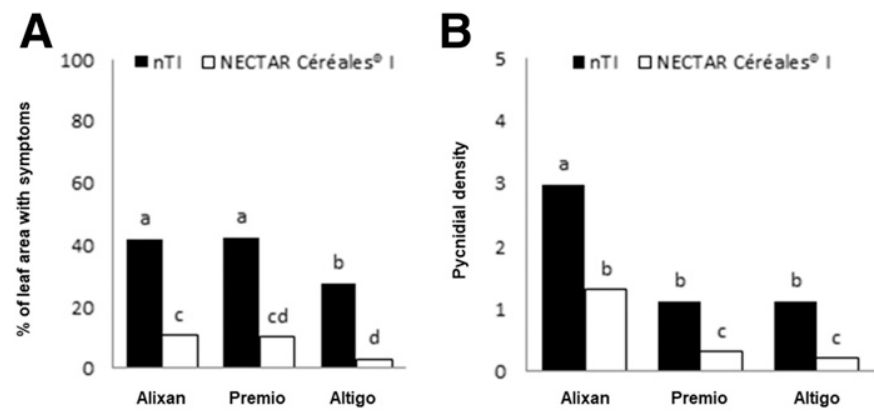

Fig. 1. Disease severity caused by Zymoseptoria tritici strain T01193 on Alixan, Premio, and Altigo wheat cultivars on nontreated inoculated control plants (nTI) and on plants treated with a plant nutrient- and microbial proteinbased resistance inducer (NECTAR Céréales) $48 \mathrm{~h}$ before inoculation (NECTAR Céréales I). A, Symptoms were evaluated by noting the percentage of the third leaf area covered by lesions (chlorosis and necrosis), and $\mathbf{B}$, the pycnidial density within symptoms was estimated on a scale from 0 (absence of pycnidia) to 5 (high density of pycnidia) at 21 days after inoculation. Means with the same letter are not significantly different using Tukey's test at $P \leq 0.05$. 
Altigo and Premio at $72 \mathrm{~h}$ after treatment than in the corresponding nTI plants.

PAL activity recorded on noninoculated plants in Alixan treated with NECTAR Céréales (3.6 nanokatal $\mathrm{mg}^{-1}$ of protein) was significantly higher than in nTnI, nTI and in inoculated NECTAR Céréales plants at $72 \mathrm{~h}$ after treatment $(0.8,1.5$, and 0.7 nanokatal $\mathrm{mg}^{-1}$ of protein, respectively) (Fig. 5A). For Premio, NECTAR Céréales-treated plants had a PAL activity (2.1 nanokatal $\mathrm{mg}^{-1}$ of protein) significantly higher than the nTnI controls (Fig. 5B). In inoculated plants, the activity recorded in Premio NECTAR Céréales plants (1.3 nanokatal $\mathrm{mg}^{-1}$ of protein) was significantly higher than in the nTnI and nTI treatments, but significantly lower than in NECTAR Céréales plants. In Altigo, the PAL activity recorded in NECTAR Céréales plants at 48 and $72 \mathrm{~h}$ after treatment (2.1 and 1.1 nanokatal $\mathrm{mg}^{-1}$ of protein, respectively) was significantly higher than in the $\mathrm{nTnI}$ control ( 1.3 and 0.9 nanokatal $\mathrm{mg}^{-1}$ of protein, respectively) (Fig. 5C). In inoculated plants, the PAL activity recorded at $72 \mathrm{~h}$ after treatment in inoculated NECTAR Céréales plants (4.6 nanokatal $\mathrm{mg}^{-1}$ of protein) was significantly higher than in NECTAR Céréales plants as well as in nTnI and nTI controls.

Induction of defense-related gene expression in Alixan, Premio, and Altigo in noninoculated plants. We established transcript profiles of a set of nine distinct defense genes associated with four types of wheat defenses: ROS metabolism (POX2, OXO) (Fig. 6), octadecanoid (LOX, AOS) (Fig. 7), phenylpropanoid (PAL, CHS) (Fig. 8) pathways, and PR protein biosynthesis (PR1, CHIT2, GLUC) (Fig. 9). Gene expression profiles in Alixan, Premio, and Altigo plants were followed at 12, 24, 48 51, 54, 60, 72, 120, and $168 \mathrm{~h}$ after treatment with NECTAR Céréales and were compared with their respective (nTnI) controls (Figs. 6, 7, 8, and 9) for which expression was considered to be at 1 . For a meaningful biological approach, significantly differentially expressed transcripts were reported according to a strict selection criterion; namely, a $\geq 2.0$-fold (upregulation) or a $<0.5$-fold (downregulation) change threshold.

Concerning ROS metabolism, the POX2 gene was induced ( $\geq 3$.2fold) in the Alixan cultivar over all the time courses except at 24, 60, and $168 \mathrm{~h}$ after treatment; in Altigo, from 3.1- to 17.3-fold at 12, 24, 48,51 , and $60 \mathrm{~h}$ after treatment; in Premio, from 4.6- to 12.5-fold at 24, 51, 54, and $60 \mathrm{~h}$ after treatment (Fig. 6). The $O X O$ gene expression was induced at $60 \mathrm{~h}$ (2.7-fold) in Premio, and at $72 \mathrm{~h}$ after treatment (4.1- and 6.8-fold, respectively) in Alixan and Altigo.

Concerning the jasmonate pathway, Premio showed an early induction of the $L O X$ gene expression level, ranging from 3.6- to 28.8-fold, at 12 to $54 \mathrm{~h}$ after treatment (Fig. 7). In Altigo, $L O X$ was induced at $24 \mathrm{~h}$ after treatment (10.1-fold). Also, $A O S$ showed an early significant induction at 5.1- to 77.2-fold, and 5.6- to 11.5fold in Premio and Altigo, respectively. However, in Alixan, this gene was induced later at 54 and $120 \mathrm{~h}$ after treatment with 6.5and 2.0-fold, respectively (Fig. 7).

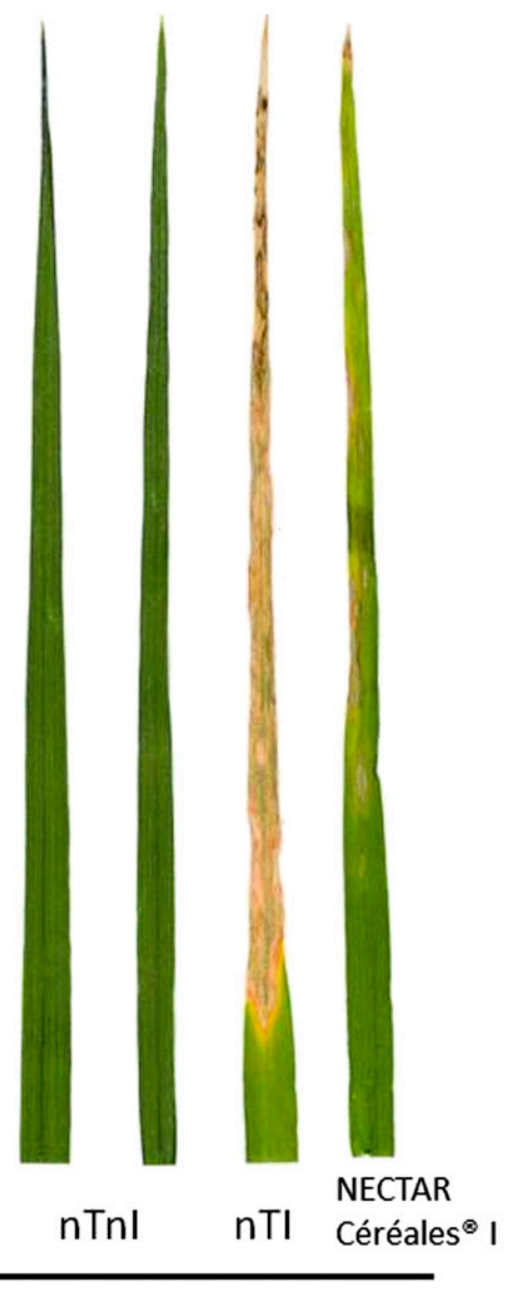

Alixan

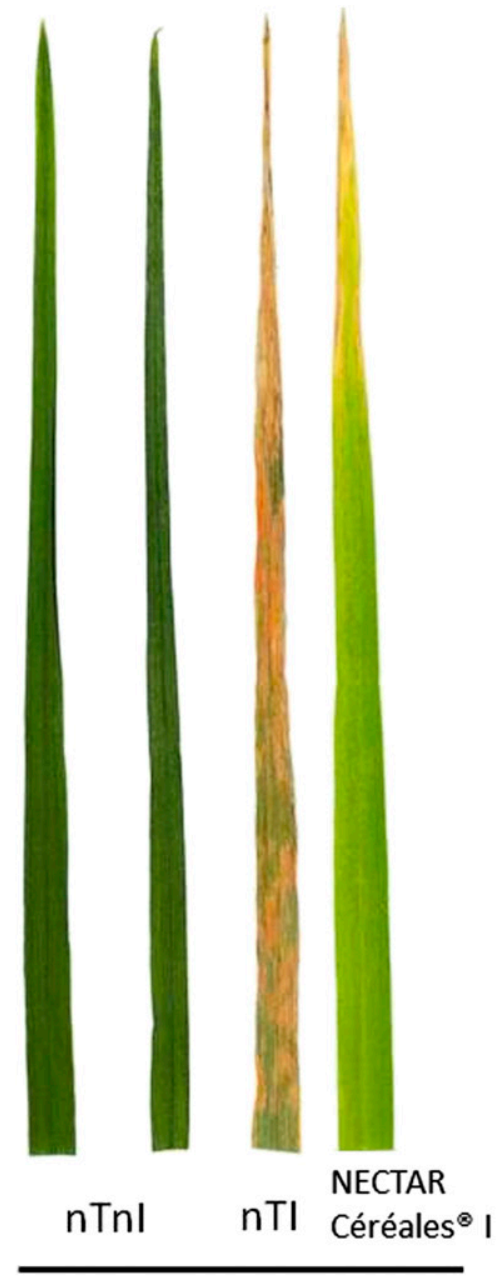

Premio

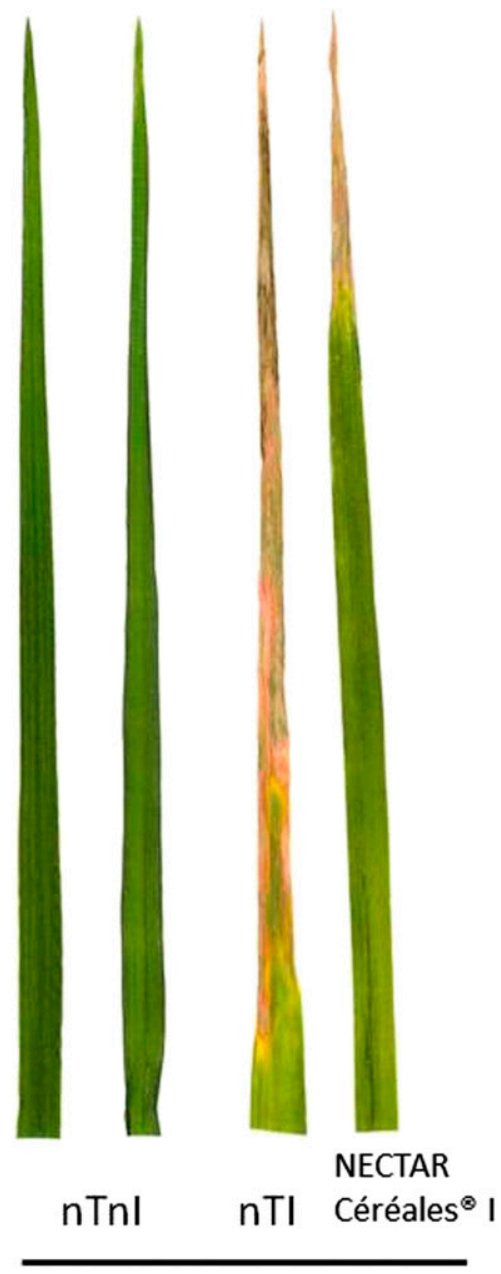

Altigo

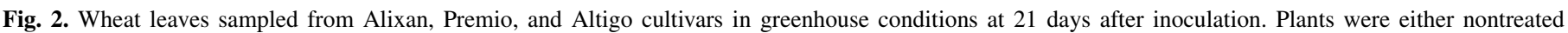

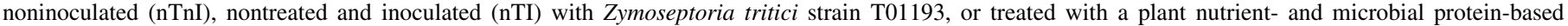
resistance inducer (NECTAR Céréales I) $48 \mathrm{~h}$ before inoculation. 


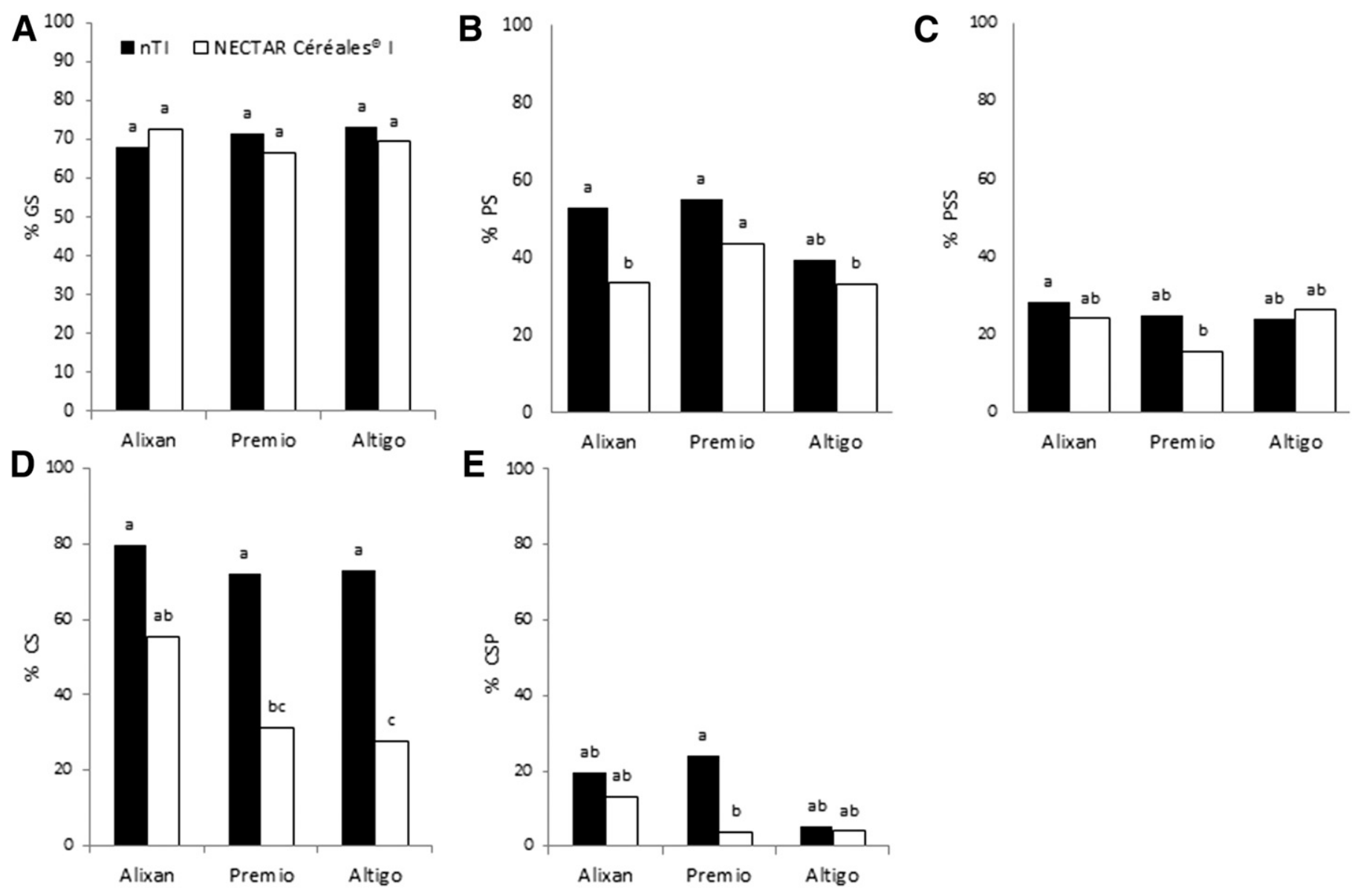

Fig. 3. Microscopic observation of the infection process of Zymoseptoria tritici on Alixan, Premio, and Altigo wheat cultivars treated with a plant nutrient- and microbial protein-based resistance inducer (NECTAR Céréales) $48 \mathrm{~h}$ before inoculation (NECTAR Céréales I), or nontreated and inoculated (nTI). A, Percentage of germinated spores (GS) at 1 day after inoculation (dai); B, percentage of total germinated spores with penetrated germ tube (PS) and C, penetrating spores through stomata (PSS) at 5 dai; and D, percentage of colonized substomatal cavities (CS) and $\mathbf{E}$, percentage of pycnidia emerging from colonized substomatal cavities (CSP) at 21 dai. Means with the same letter are not significantly different using Tukey's test at $P \leq 0.05$.

TABLE 1. Time course of $\beta-1,4$-endoxylanase activity (units $\mathrm{mg}^{-1}$ of total protein) in Alixan, Premio, and Altigo wheat cultivars treated with a plant nutrient- and microbial protein-based resistance inducer (NECTAR Céréales) $48 \mathrm{~h}$ before inoculation with Zymoseptoria tritici strain T01193z

\begin{tabular}{|c|c|c|c|c|c|c|}
\hline Cultivar & Treatment & 1 dai & 5 dai & 11 dai & 17 dai & 21 dai \\
\hline \multirow[t]{3}{*}{ Alixan } & Nontreated noninoculated & $0.01 \mathrm{~b}$ & $0.01 \mathrm{a}$ & $0.01 \mathrm{a}$ & $0.03 \mathrm{bc}$ & $0.02 \mathrm{~d}$ \\
\hline & Nontreated inoculated & $0.02 \mathrm{ab}$ & $0.01 \mathrm{a}$ & $0.01 \mathrm{a}$ & $0.08 \mathrm{a}$ & $0.34 \mathrm{a}$ \\
\hline & Treated inoculated & $0.02 \mathrm{ab}$ & $0.02 \mathrm{a}$ & $0.02 \mathrm{a}$ & $0.03 \mathrm{bc}$ & $0.10 \mathrm{~b}$ \\
\hline \multirow{2}{*}{ Premio } & Nontreated inoculated & $0.01 \mathrm{ab}$ & $0.01 \mathrm{a}$ & $0.02 \mathrm{a}$ & $0.04 \mathrm{ab}$ & $0.08 \mathrm{~b}$ \\
\hline & Treated inoculated & $0.02 \mathrm{a}$ & $0.01 \mathrm{a}$ & $0.01 \mathrm{a}$ & $0.02 \mathrm{~cd}$ & $0.07 \mathrm{~b}$ \\
\hline \multirow[t]{2}{*}{ Altigo } & Nontreated noninoculated & $0.02 \mathrm{ab}$ & $0.01 \mathrm{a}$ & $0.01 \mathrm{a}$ & $0.02 \mathrm{~cd}$ & $0.02 \mathrm{~d}$ \\
\hline & Nontreated inoculated & $0.02 \mathrm{ab}$ & $0.01 \mathrm{a}$ & $0.01 \mathrm{a}$ & $0.03 \mathrm{bc}$ & $0.05 \mathrm{bc}$ \\
\hline
\end{tabular}

${ }^{\mathrm{z}}$ At each time point (1 to 21 days after inoculation [dai]), activity levels were compared with nontreated noninoculated and nontreated inoculated controls. Means with the same letter at each time point are not significantly different using Tukey's test at $P \leq 0.05$.

TABLE 2. Time course of $\beta-1,4$-endoglucanase activity (units $\mathrm{mg}^{-1}$ of total protein) in Alixan, Premio, and Altigo wheat cultivars treated with a plant nutrient- and microbial protein-based resistance inducer (NECTAR Céréales) $48 \mathrm{~h}$ before inoculation with Zymoseptoria tritici strain T01193z

\begin{tabular}{|c|c|c|c|c|c|c|}
\hline Cultivar & Treatment & 1 dai & 5 dai & 11 dai & 17 dai & 21 dai \\
\hline \multirow[t]{3}{*}{ Alixan } & Nontreated noninoculated & $0.06 \mathrm{ab}$ & $0.08 \mathrm{a}$ & $0.08 \mathrm{a}$ & $0.10 \mathrm{bc}$ & 0.09 ef \\
\hline & Nontreated inoculated & $0.06 \mathrm{ab}$ & $0.08 \mathrm{a}$ & $0.09 \mathrm{a}$ & $0.21 \mathrm{a}$ & $0.62 \mathrm{a}$ \\
\hline & Treated inoculated & $0.07 \mathrm{ab}$ & $0.09 \mathrm{a}$ & $0.1 \mathrm{a}$ & $0.12 \mathrm{bc}$ & $0.26 \mathrm{~b}$ \\
\hline & Nontreated inoculated & $0.06 \mathrm{ab}$ & $0.07 \mathrm{a}$ & $0.09 \mathrm{a}$ & $0.14 \mathrm{ab}$ & $0.18 \mathrm{bcd}$ \\
\hline & Treated inoculated & $0.08 \mathrm{a}$ & $0.07 \mathrm{a}$ & $0.09 \mathrm{a}$ & $0.09 \mathrm{~cd}$ & $0.24 \mathrm{bc}$ \\
\hline \multirow[t]{2}{*}{ Altigo } & Nontreated noninoculated & $0.05 \mathrm{~b}$ & $0.07 \mathrm{a}$ & $0.08 \mathrm{a}$ & $0.12 \mathrm{bc}$ & $0.09 \mathrm{ef}$ \\
\hline & Nontreated inoculated & $0.05 \mathrm{~b}$ & $0.07 \mathrm{a}$ & $0.07 \mathrm{a}$ & $0.10 \mathrm{bc}$ & $0.15 \mathrm{~cd}$ \\
\hline
\end{tabular}

z At each time point (1 to 21 days after inoculation [dai]), activity levels were compared with nontreated noninoculated and nontreated inoculated controls. Means with the same letter at each time point are not significantly different using Tukey's test at $P \leq 0.05$. 
Concerning the salicylic acid (SA) pathway, an early induction of $P A L$, the gene marker of the phenylpropanoid pathway, was recorded in Altigo with a 2.3-fold increase at $12 \mathrm{~h}$ after treatment and reaching 35.0-fold at $72 \mathrm{~h}$ (Fig. 8). It was induced at 48 to $120 \mathrm{~h}$ (ranging from 2.7- to 14.0-fold) in Alixan and at $60 \mathrm{~h}$ only in Premio (2.3-fold). Concerning the $C H S$ gene, Altigo showed induction at 54 and $72 \mathrm{~h}$ (22.1- and 15.0-fold, respectively).
Concerning PR protein biosynthesis, Altigo showed an early induction of $P R l$, the SA pathway marker of systemic acquired resistance, at 24 and $60 \mathrm{~h}$ (2.3- and 3.0-fold, respectively) (Fig. 9). In Alixan, $P R I$ was induced at 48 and $51 \mathrm{~h}$ (6.2- and 18.1-fold, respectively). CHIT2 gene expression was induced in Altigo at 12 and $72 \mathrm{~h}$ (4.6- and 5.9-fold, respectively), whereas in Alixan, it was only induced at $72 \mathrm{~h}$ (9.1-fold). No induction was observed in

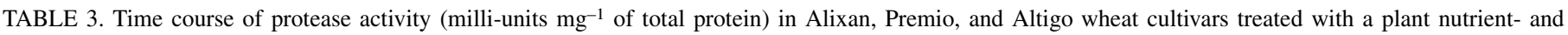
microbial protein-based resistance inducer (NECTAR Céréales) $48 \mathrm{~h}$ before inoculation with Zymoseptoria tritici strain T01193z

\begin{tabular}{|c|c|c|c|c|c|c|}
\hline Cultivar & Treatment & 1 dai & 5 dai & 11 dai & 17 dai & 21 dai \\
\hline \multirow[t]{3}{*}{ Alixan } & Nontreated noninoculated & $0.05 \mathrm{ab}$ & $0.13 \mathrm{a}$ & $0.08 \mathrm{a}$ & $0.09 \mathrm{bc}$ & $0.04 \mathrm{c}$ \\
\hline & Nontreated inoculated & $0.07 \mathrm{ab}$ & $0.08 \mathrm{ab}$ & $0.06 \mathrm{ab}$ & $0.85 \mathrm{a}$ & $2.66 \mathrm{a}$ \\
\hline & Treated inoculated & $0.07 \mathrm{ab}$ & $0.09 \mathrm{ab}$ & $0.03 \mathrm{ab}$ & $0.22 \mathrm{~b}$ & $1.12 \mathrm{ab}$ \\
\hline \multirow[t]{3}{*}{ Premio } & Nontreated noninoculated & $0.10 \mathrm{a}$ & $0.13 \mathrm{a}$ & $0.03 \mathrm{ab}$ & $0.05 \mathrm{c}$ & $0.05 \mathrm{c}$ \\
\hline & Nontreated inoculated & $0.05 \mathrm{ab}$ & $0.06 \mathrm{ab}$ & $0.05 \mathrm{ab}$ & $0.07 \mathrm{bc}$ & $0.51 \mathrm{~b}$ \\
\hline & Treated inoculated & $0.02 \mathrm{~b}$ & $0.05 \mathrm{ab}$ & $0.03 \mathrm{~b}$ & $0.09 \mathrm{bc}$ & $0.07 \mathrm{c}$ \\
\hline \multirow[t]{3}{*}{ Altigo } & Nontreated noninoculated & $0.06 \mathrm{ab}$ & $0.08 \mathrm{ab}$ & $0.06 \mathrm{ab}$ & $0.07 \mathrm{bc}$ & $0.02 \mathrm{c}$ \\
\hline & Nontreated inoculated & $0.08 \mathrm{a}$ & $0.04 \mathrm{~b}$ & $0.06 \mathrm{ab}$ & $0.15 \mathrm{bc}$ & $0.72 \mathrm{ab}$ \\
\hline & Treated inoculated & $0.03 \mathrm{ab}$ & $0.07 \mathrm{ab}$ & $0.05 \mathrm{ab}$ & $0.12 \mathrm{bc}$ & $0.57 \mathrm{~b}$ \\
\hline
\end{tabular}

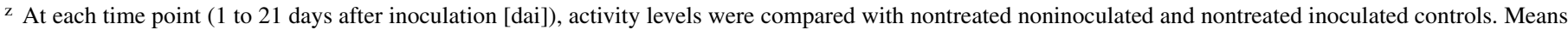
with the same letter at each time point are not significantly different using Tukey's test at $P \leq 0.05$.

A

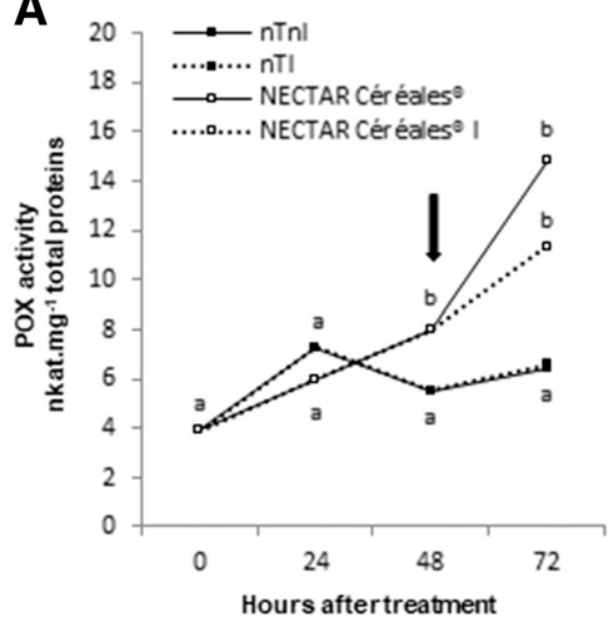

B

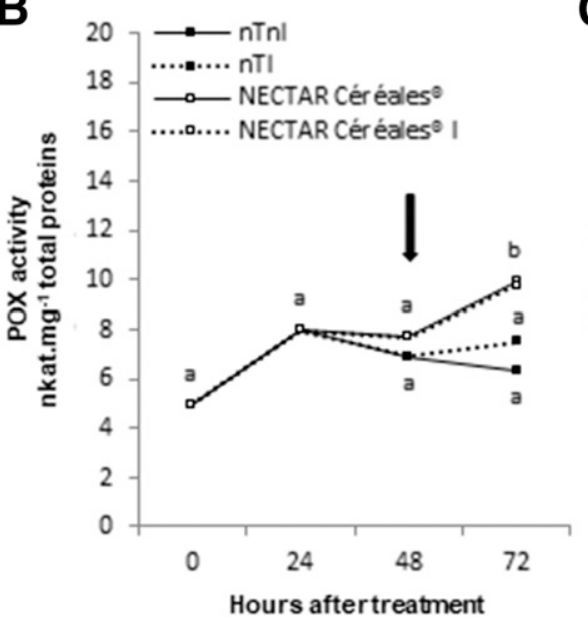

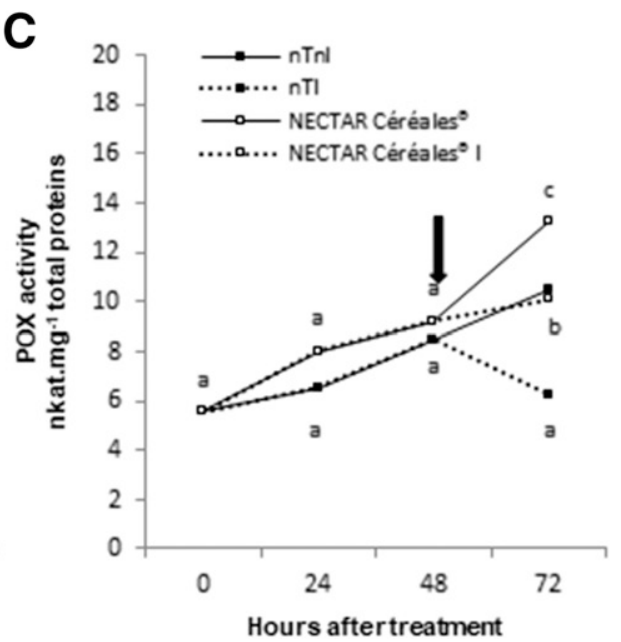

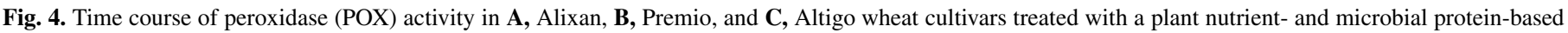

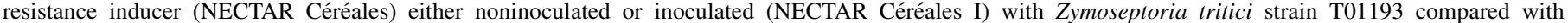

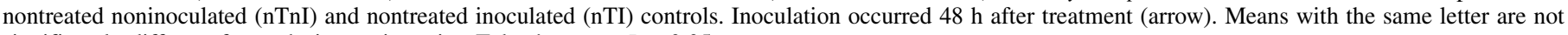
significantly different for each time point using Tukey's test at $P \leq 0.05$.
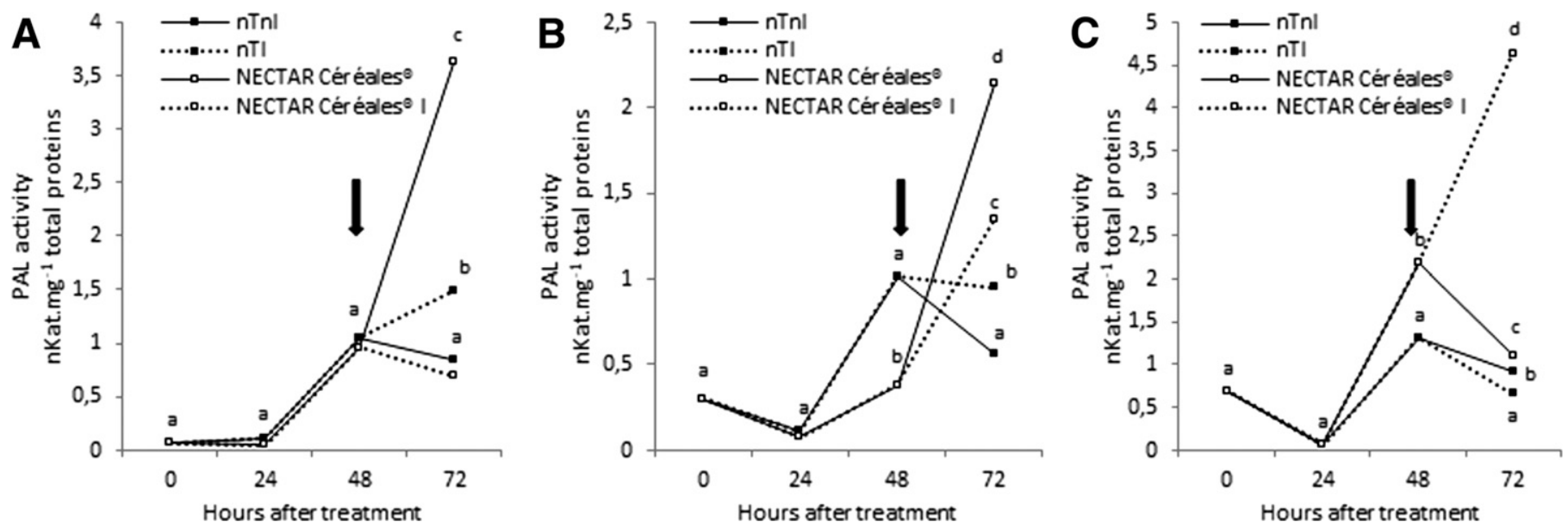

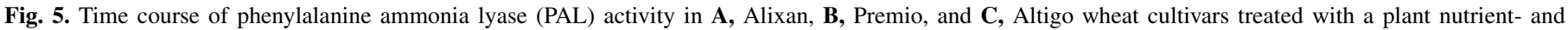

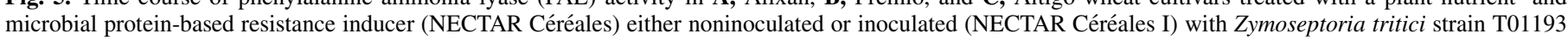

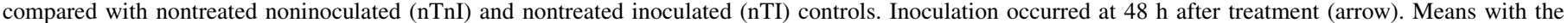
same letter are not significantly different for each time point using Tukey's test at $P \leq 0.05$. 
Premio. The GLUC gene was induced in Premio at 12 to $54 \mathrm{~h}$ with 2.5- to 5.1-fold overexpression. In Alixan, this gene induction was recorded at 24 to $54 \mathrm{~h}$ with $2.7-$, to 9.8 -fold increase and at 60 and $72 \mathrm{~h}$ in Altigo with 2.1- and 5.2-fold increase, respectively.

Induction of defense-related gene expression in Alixan, Premio, and Altigo in inoculated plants. The transcription profiles of the same set of gene were also established in plants treated with
NECTAR Céréales and inoculated. Gene expression profiles were followed at 6,12 , and $24 \mathrm{~h}$ after inoculation and were compared with nTnI controls (Fig. 10). Only genes that were significantly regulated following infection are displayed.

The POX2 gene expression level recorded in Alixan NECTAR Céréales-treated and inoculated plants at $6 \mathrm{~h}$ after inoculation (68fold) was significantly higher than in nTI controls (17.8-fold) and
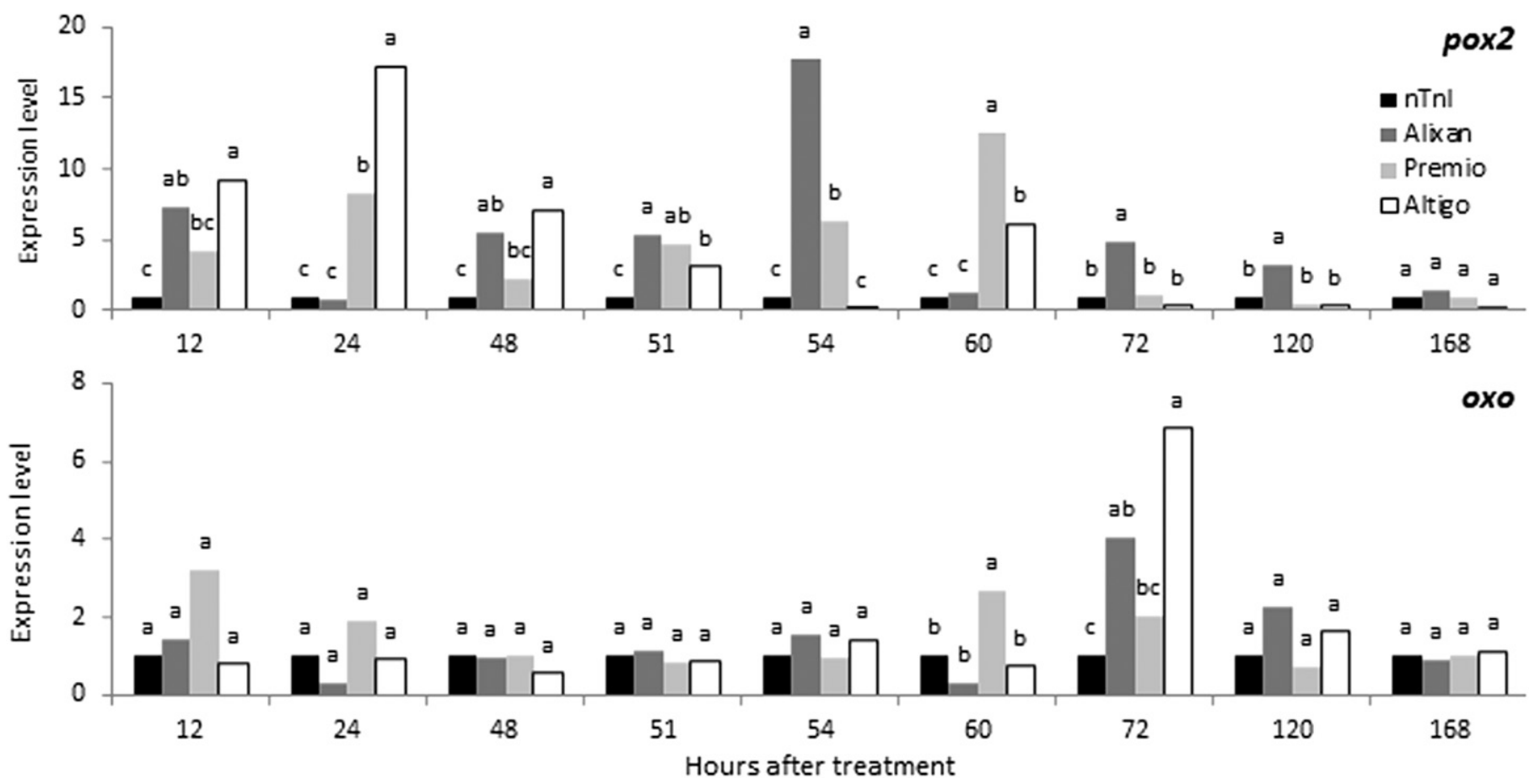

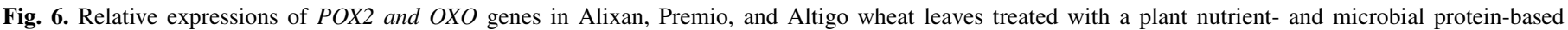

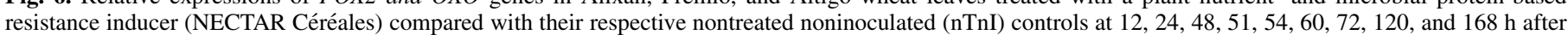
treatment. Means with the same letter are not significantly different for each time point using Tukey's test at $P \leq 0.05$.
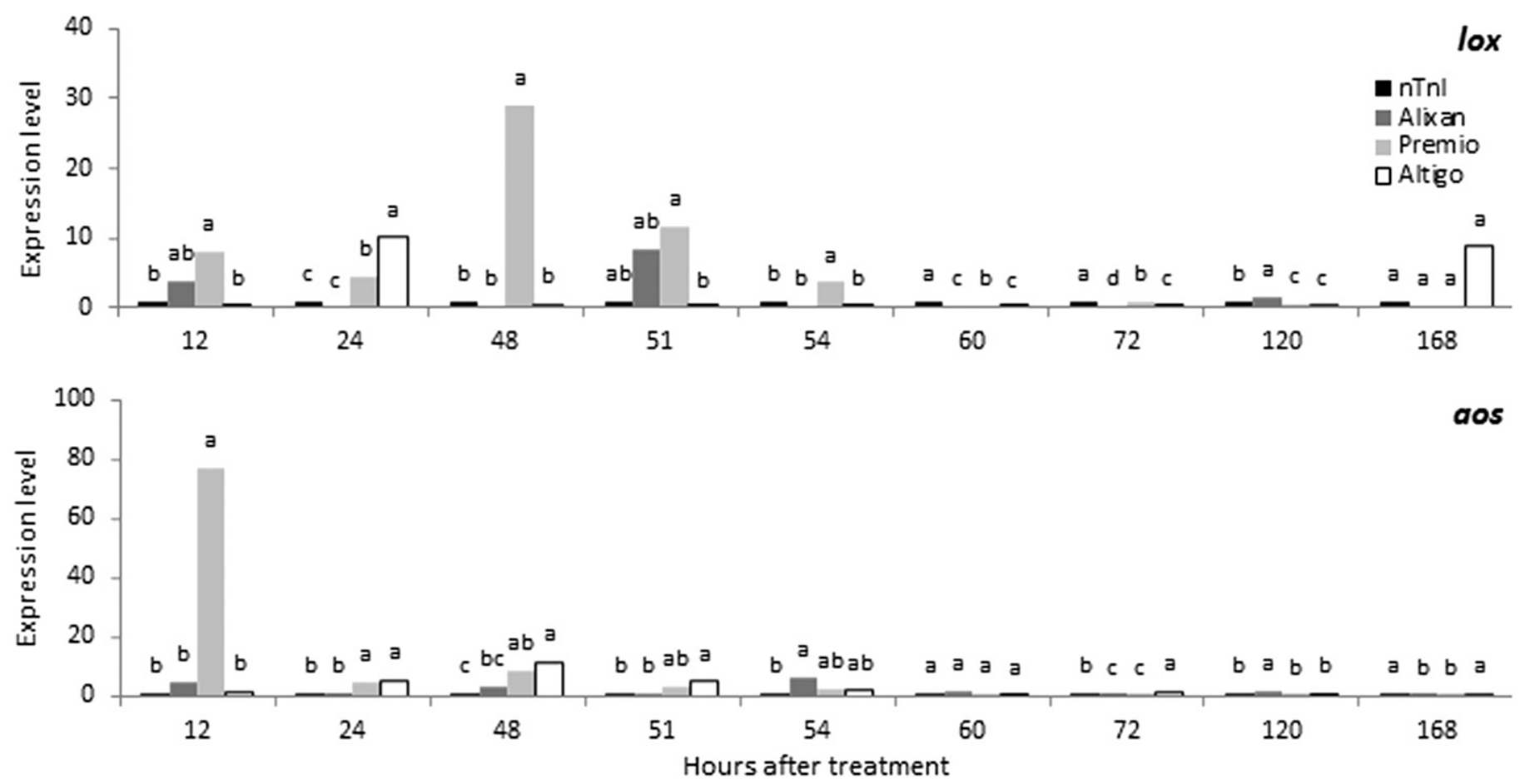

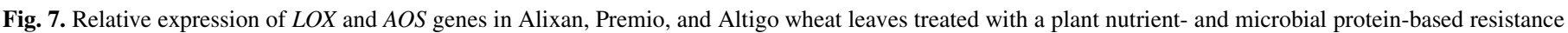

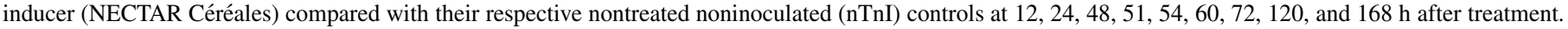
Means with the same letter are not significantly different for each time point using Tukey's test at $P \leq 0.05$. 
in NECTAR Céréales -treated plants (17.3-fold), whereas no significant increase was recorded in Premio and Altigo.

The $P A L$ gene was significantly upregulated in Alixan and Altigo NECTAR Céréales-treated and inoculated plants at $6 \mathrm{~h}$ after inoculation (26.7-fold) and at $24 \mathrm{~h}$ after inoculation (84.64-fold) relative to the nTI controls (Fig. 10). In Premio, NECTAR Céréalestreated and inoculated plants presented no significant induction of this gene.

The PRl gene was significantly upregulated in Alixan NECTAR Céréales-treated and inoculated plants at $12 \mathrm{~h}$ after inoculation (7.4-fold) compared with nTI controls (0.4-fold) and NECTAR Céréales-treated plants (1.4-fold). No significant induction of this gene was observed in Premio and Altigo. Concerning the GLUC gene, its expression was significantly higher at 6 and $12 \mathrm{~h}$ after inoculation in Alixan (7.4- and 2.6-fold, respectively) than in nTI plants (0.9- and 0.5-fold, respectively) and in NECTAR Céréalestreated plants (2.7- and 0.4-fold, respectively). This gene expression level recorded at 12 and $24 \mathrm{~h}$ after inoculation in Altigo NECTAR Céréales-treated and inoculated plants (5.9- and 32.5fold, respectively) was significantly higher than in nTI (2.6- and 0.9 -fold, respectively) and in NECTAR Céréales-treated plants (2.1- and 5.2-fold, respectively). In Premio NECTAR Céréalestreated and inoculated plants, the $G L U C$ gene expression level was not significantly different from nTI and NECTAR Céréalestreated plants.

\section{DISCUSSION}

The present study aimed to evaluate the elicitor potential of a sulfur, manganese sulfate and microbial protein-based commercial product, NECTAR Céréales, against STB, taking into account the wheat genotype response. During the first part of our project, we determined the efficient dose, timing, and number of applications of NECTAR Céréales (previously named FSOV7) to protect wheat against STB (Ors et al. 2012, 2013). Significant reductions $>70 \%$ of disease symptoms and $>50 \%$ of pathogen sporulation on the three studied cultivars were obtained when leaves were pretreated $48 \mathrm{~h}$ before inoculation with $30 \mathrm{ml}$ of NECTAR Céréales at the dose of $8.73 \mu \mathrm{l} / \mathrm{ml}$. While the efficient dose of this product did not show any direct effect on spore germination and mycelium growth, the upregulation of at least one wheat defense gene marker, such as POX2, PAL, LOX, AOS, $O X O, C H I T 2$ or GLUC genes was recorded in the three studied cultivars after leaf pretreatment. The involvement of these genes in the resistance of wheat to $Z$. tritici was suggested previously in numerous studies (Adhikari et al. 2007; Diani et al. 2009; Ors et al. 2017; Samain et al. 2017; Shetty et al. 2009; Yang et al. 2013b).

Many microbial proteins have been identified as inducers of plant resistance to pathogen attack. The pebC1 protein from Botrytis cinerea reduced gray mold in tomato (Zhang et al. 2010, 2014b), an elicitin and a $75 \mathrm{kDa}$ protein elicitor purified from Phytophthora palmivora induced resistance in Hevea brasiliensis against this pathogen (Dutsadee and Nunta 2008), the SsCut cutinase from Sclerotinia sclerotiorum induced defense mechanisms in various plant species (Zhang et al. 2014a) and the Hrip1 protein from Alternaria tenuissima elicited defense mechanisms in tobacco (Kulye et al. 2012). However, minerals and ions are also able to induce defenses in plants against pathogens. Low concentrations of $\mathrm{CuSO}_{4}$ elicited the production of phytoalexins in grapevine leaves and protected them against $B$. cinerea and Plasmopara viticola (Aziz et al. 2006). Moreover, high leaf manganese concentrations induced protection against Erysiphe necator, responsible for powdery mildew in grapevine, and the synthesis of proteins related to pathogen resistance (Yao et al. 2012).

Nevertheless, a light chlorosis was observed on wheat leaves treated with NECTAR Céréales. Previously, Fecht-Christoffers et al. (2003) described similar symptoms in cowpea leaves caused by the toxic effect of an excessive manganese supply. The authors reported an increase of POX activity and an accumulation of proteins showing homologies to PR-proteins such as glucanase and chitinase. As discussed below, treatment with NECTAR Céréales induces similar accumulations in the wheat cultivars

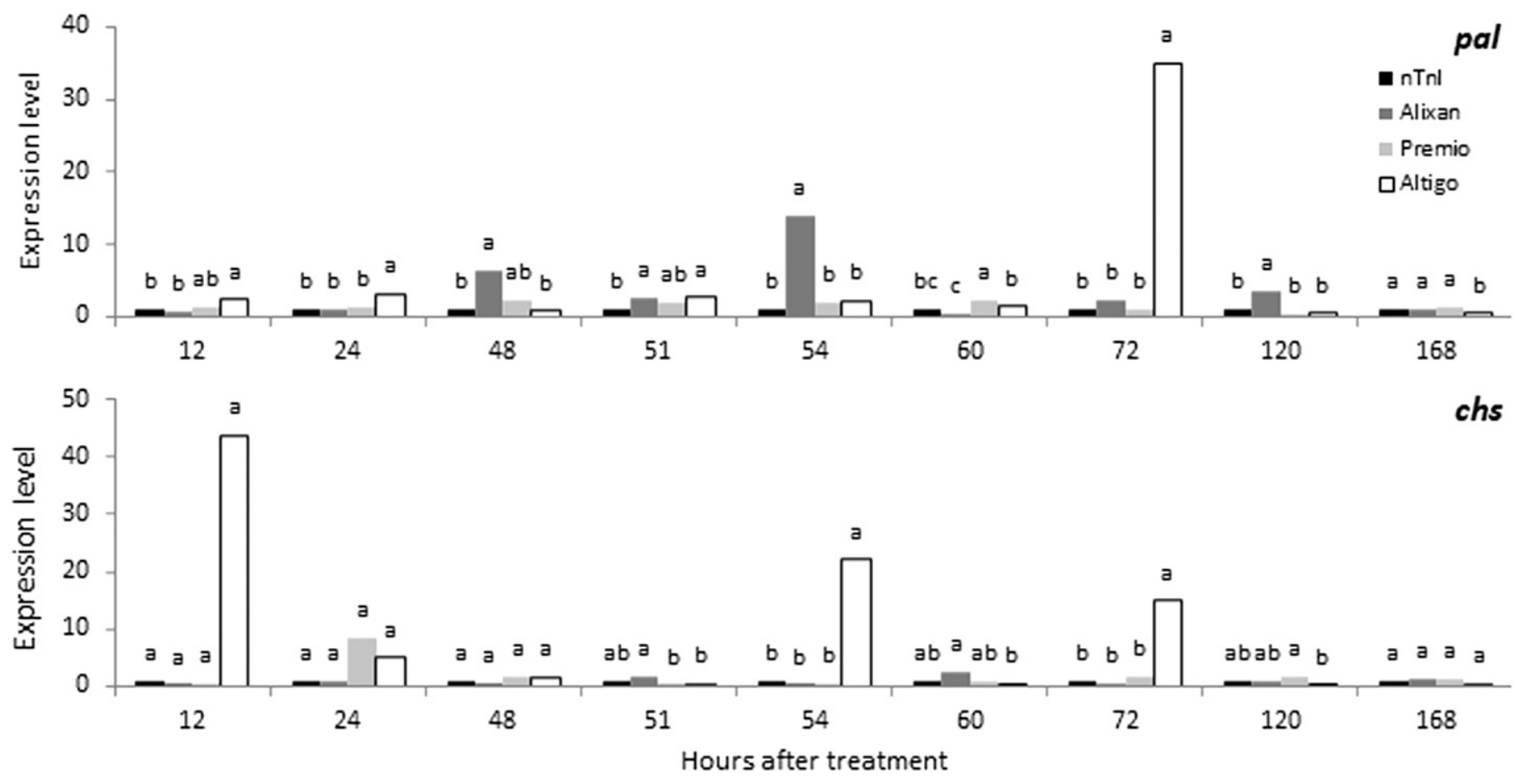

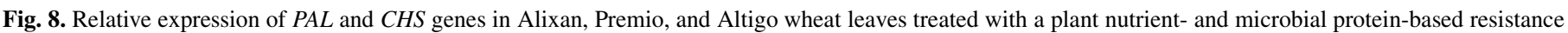

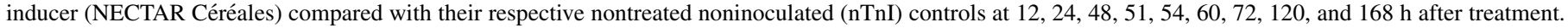
Means with the same letter are not significantly different for each time point using Tukey's test at $P \leq 0.05$. 
Alixan, Premio, and Altigo. It is possible that manganese contained in NECTAR Céréales is at least partially responsible for such induction and possibly involved in the slight toxicity observed during the induced resistance. Abiotic stresses, such as an excessive Mn supply, could induce plant defense mechanisms. Mithöfer et al. (2004) hypothesized that heavy metals as well as biotic stress lead to an accumulation of the reactive oxygen species (ROS) involved in the oxidation of unsaturated fatty acids which initiate the octadecanoid pathway. The authors suggested that the formation of oxylipins (through LOX and AOS activities) could elicit plant secondary metabolism and accumulation of defense compounds as induced by a biotic stress. Taken together, these results suggest that the protection efficacy conferred by NECTAR Céréales on wheat against $Z$. tritici results from the induction of resistance mechanisms that could be attributed to one or several of its components.

Whatever the cultivar, wheat defense responses were activated during the first $72 \mathrm{~h}$ after treatment, even if many differences concerning timing and intensity were recorded between cultivars. More specifically, the RT-qPCR analysis showed an important upregulation of $P O X 2$ as a response to NECTAR Céréales pretreatment in the three wheat cultivars, in noninoculated plants. At the biochemical level, our results confirmed the elicitation of POX activity in the three cultivars $72 \mathrm{~h}$ after treatment. The pox gene encodes for the peroxidase enzyme which plays an important role in the ROS pathway by catalyzing genes implicated in oxidative radicals. In addition, peroxidases are implicated in lignin production and in plant cell wall reinforcement (Pechanova et al. 2010). This mode of action represent the first physical defense barrier to pathogen attack (Underwood 2012). In addition to lignification, oxidative radicals with other related defense proteins and polysaccharides have restricted strongly cell wall invasion by fungal pathogens including Verticillium spp. and Melampsora spp. (Pechanova et al. 2010; Floerl et al. 2012). Also, the overexpression of the hydrogen peroxide $\left(\mathrm{H}_{2} \mathrm{O}_{2}\right)$-producing enzyme oxalate oxidase $(O X O)$ as a response to NECTAR Céréales pretreatment indicates the implication of $\mathrm{H}_{2} \mathrm{O}_{2}$ in the induced resistance against $\mathrm{STB}$. Indeed, $\mathrm{H}_{2} \mathrm{O}_{2}$ has shown direct antagonistic effect against phytopathogenic microorganisms (Peng and Kuc 1992). Previously, a correlation between $O X O$ gene expression and resistance to Sphaerulina musiva has been reported (Liang et al. 2001). The production of ROS was reported as an earlier response during the biotrophic phase of $Z$. tritici starting at the infection point and expanding to the entire leaf tissue during the necrotrophic phase (Yang et al. 2015). In contrast to necrotrophs, which often enhance ROS production to stimulate programmed cell death and facilitate nutrient uptake (Govrin and Levine 2000), this mode of action could be efficient in stopping the
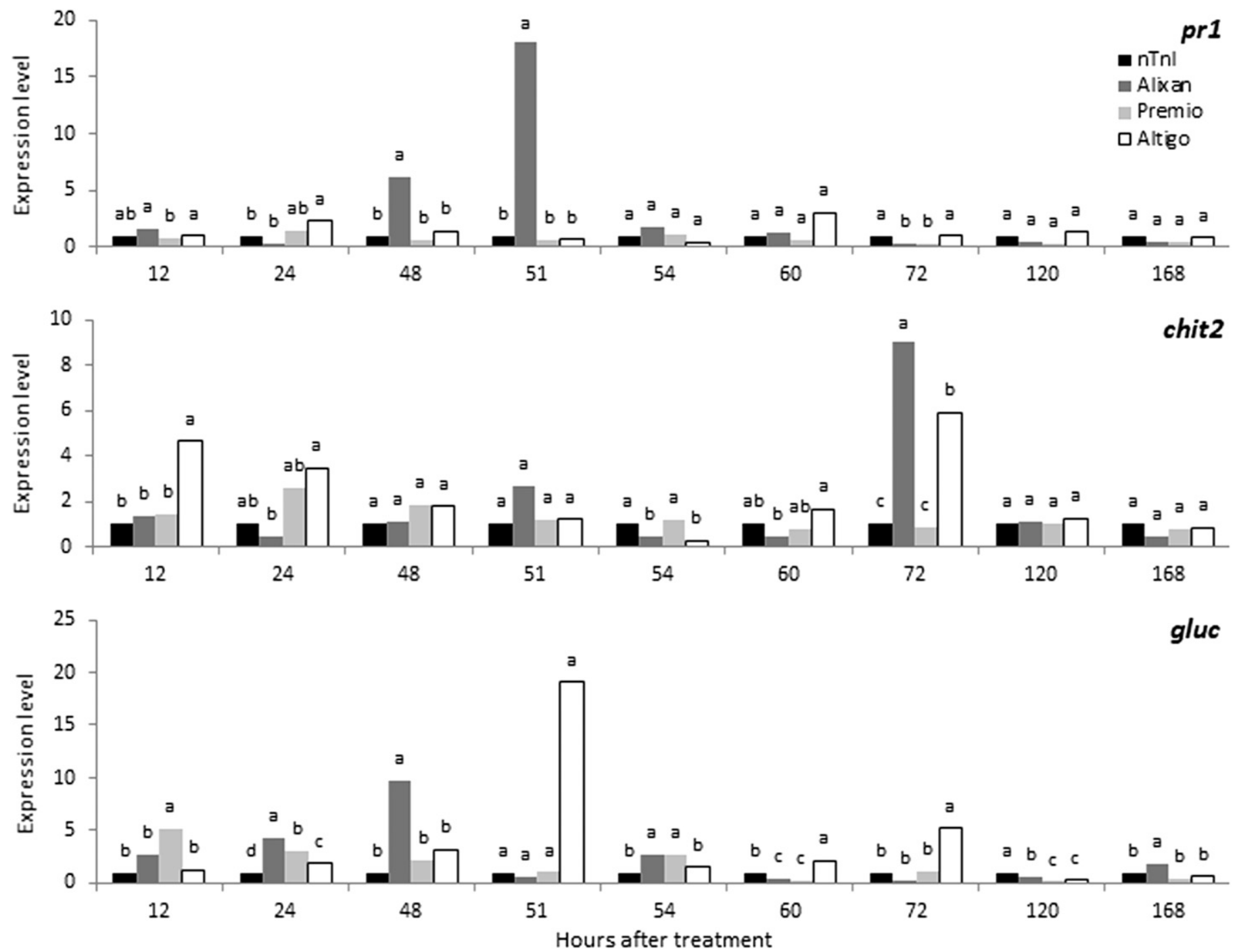

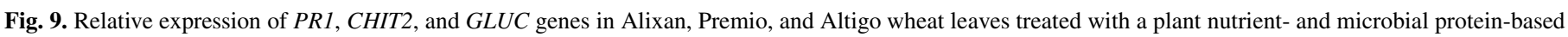

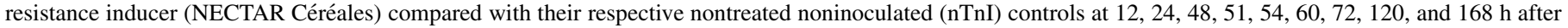
treatment. Means with the same letter are not significantly different for each time point using Tukey's test at $P \leq 0.05$. 
infection process of $Z$. tritici, which reacts as a biotroph during the first 9 days of its contact with wheat plants (Selim et al. 2014).

However, our results showed variations between cultivars at the level of elicitation timing and upregulation intensities of other tested genes. Such variations were interpreted previously as the impact of the plant genotype (Bruce 2014; Samain et al. 2019; Walters et al. 2005, 2011). In contrast to Alixan and Premio, the most resistant cultivar Altigo treated with NECTAR Céréales
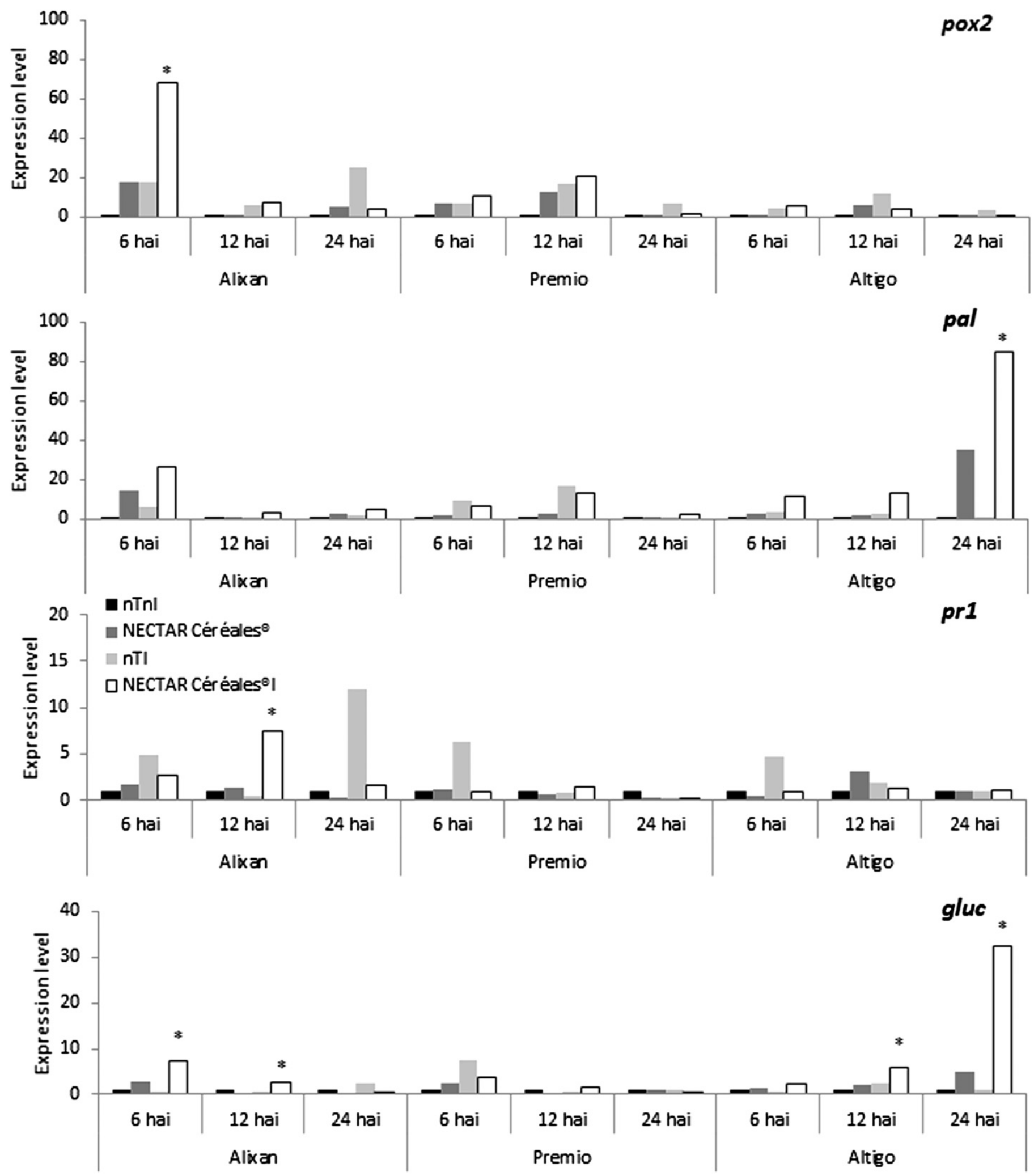

Fig. 10. Relative expression of $P O X 2, P A L, P R 1$, and GLUC genes in Alixan, Premio, and Altigo wheat leaves treated with a plant nutrient- and microbial proteinbased resistance inducer (NECTAR Céréales) either noninoculated or inoculated (NECTAR Céréales I) with Zymoseptoria tritici strain T01193 compared with nontreated noninoculated (nTnI) and nontreated inoculated (nTI) controls at 6, 12, and $24 \mathrm{~h}$ after inoculation. Inoculation occurred at $48 \mathrm{~h}$ after treatment. Means with an asterisk are significantly higher than in nontreated noninoculated, nontreated inoculated, and treated noninoculated plants for each cultivar and for each time point using Tukey's test at $P \leq 0.05$. 
exhibited an earlier and a significant upregulation of the $P A L$ and the $C H S$ genes at $12 \mathrm{~h}$ in noninoculated plants. The overexpression of $P A L$ reached a maximum at $72 \mathrm{~h}$ and was associated with a high induction level of $C H S$ and with transient but significant inductions of chit, GLUC and $O X O$ genes. The PAL and $C H S$ genes encode for phenylalanine ammonia-lyase and chalcone synthase enzymes, respectively, that are known as markers of the phytoalexin and phenylpropanoid pathway. Indeed, PAL catalyzes phenylalanine as the first step of serial reactions where many other enzymes such as CHS are implicated. Theses reactions result to the biosynthesis of large varieties of compounds with antimicrobial and antioxidant activities, flavonoids, phytoalexins, and lignin (Lamb and Dixon 1997). In addition, the upregulation of chit and GLUC genes coding for chitinase and glucanase enzymes could be efficient in the control of $Z$. tritici by their known role in the digesting of chitin and $\beta$-glucans, respectively, of the fungal cell wall (Samain et al. 2017). Moreover, after inoculation with Z. tritici, the same defense pathways are still stimulated in Altigo treated with NECTAR Céréales, since an overexpression of $P A L$ and GLUC genes was observed during the first $24 \mathrm{~h}$ after infection compared with plants treated with NECTAR Céréales only or inoculated with $Z$. tritici only. Hence, the phenylpropanoid pathway and glucanase seem involved in Altigo's defense response induced by NECTAR Céréales against $Z$. tritici.

In the moderately resistant wheat cultivar Premio, any of the tested genes were up-regulated following inoculation after treatment. Defenses mechanisms were mainly induced just after treatment, suggesting an eliciting effect rather than a priming effect of NECTAR Céréales in this cultivar. In the noninoculated plants, $L O X$ and $A O S$ gene expression were strongly up-regulated at the same times after 12,24 , and $48 \mathrm{~h}$ indicating the stimulation of jasmonic acid and ethylene signaling pathways. LOX and AOS enzymes are implicated in the biosynthesis of the oxylipins (Gottwald et al. 2012) which are involved in pathogen recognition (Wasternack 2007) and in different plant defense mechanisms such as proteinase inhibitor induction, secondary metabolite accumulation and eliciting of other defenses such as PR genes (Blée 2002; Mithöfer et al. 2004; Robert-Seilaniantz et al. 2007). Moreover, some of them, such as thaumatin-like proteins have fungicidal activities inhibiting spore germination and mycelium development (Prost, 2005).

In the most susceptible cultivar Alixan treated with NECTAR Céréales, in noninoculated plants, a significant up-regulation of different genes (such as POX2,OXO,PAL, PR1, CHIT2, and $G L U C)$ as well as an increase of POX and PAL activities were recorded and sometimes earlier (e.g., pox at $12 \mathrm{~h}$ ) and stronger (e.g., PRI 18.1-fold at $51 \mathrm{~h}$ ) than in Premio and Altigo. Moreover, in inoculated plants, a priming effect of NECTAR Céréales in Alixan was noticed through the induction of an overexpression of pox, $P R 1$, $P A L$, and $G L U C$ at 6 and $12 \mathrm{~h}$ after infection. The association of overexpression of $P R 1, P R 2$ ( $\beta$-1,3-glucanase), and pox, which have been identified previously as types of PR protein (Van Loon and Van Strien 1999), were observed more in incompatible than in compatible interactions in several cereal pathosystems (Boyd et al. 1994; Desmond et al. 2008) and especially in the wheat-Z. tritici pathosystem (Adhikari et al. 2007; Ray et al. 2003; Samain et al. 2019). This suggests that $P R l$ proteins may play an important role in the resistance against $Z$. tritici alone or in concert with other defense-related genes or pathways such as phenylpropanoid and ROS pathways. The absence of $P R I$ overexpression in the other two cultivars Premio and Altigo as a response to NECTAR Céréales pretreatment contradicts the idea that $P R I$ is the wheat protection marker against STB, as previously proposed by Adhikari et al. (2007) and Samain et al. (2019). The percentage of germinated spores with penetrated germ tubes (PS) recorded at 5 days after inoculation was reduced in Alixan treated with NECTAR Céréales compared with nontreated plants, suggesting that in this cultivar, the elicitation of POX2, OXO,PR1, PAL, CHIT2, and GLUC gene expression as well as the increase of $P O X 2, P R 1, P A L$, and $G L U C$ gene expression in inoculated plants affect the penetration of $Z$. tritici. A high level of gene expression seems to be required, since in this susceptible cultivar, $P O X 2, C H I T 2$ and $P R 1$ are already induced after infection and without NECTAR Céréales pretreatment (Ors et al. 2017).

The effect of NECTAR Céréales on the pathogenicity of $Z$. tritici was investigated at the cytological and biochemical levels. Results showed that CWDE activities increased on the three wheat cultivars according to the sporulation level of $Z$. tritici and the highest levels were recorded in the most susceptible cultivar Alixan at 21 days after inoculation. It has been previously reported that CWDE activities are correlated with pycnidial formation (Douaiher et al. 2007a, b; Siah et al. 2010a) and wheat susceptibility (Tian et al. 2009). As a response to pretreatment with NECTAR Céréales, CWDE activities were reduced significantly in Alixan only (except protease activity which was also reduced in Premio). Surprisingly, the pretreatment with NECTAR Céréales affected the colonization of substomatal cavities in Premio and Altigo but not in Alixan, where the reduction of CWDE activities was most important. According to microscopic observations, only direct penetration attempts were reduced in Alixan. At the macroscopic level, leaf areas with symptoms and sporulation level were both reduced in the three cultivars. However, the reduction of CWDE activities cannot be considered as a strict marker of induced resistance as a response to the elicitor pretreatment in wheat against STB since a protection has been obtained without influencing these enzymatic activities.

In conclusion, under controlled conditions, NECTAR Céréales, a manganese, sulfur- and microbial protein-based product, induces a non-genotype-specific wheat resistance conferring more than $70 \%$ of protection against $Z$. tritici. Nevertheless, the mechanisms of this induced resistance were genotype dependent and can be linked to an elicitor or both elicitor and priming effects. However, these defense pathways could impact the penetration process and the first days after infection in some cultivars or could interfere later with the fungus spreading in the leaf tissues, leading to symptom and sporulation reduction. It seems that manganese contained in NECTAR Céréales induces an abiotic stress leading to plant defense responses and chlorosis. Such an effect may be reduced at the field level by applying a lower dose or treating more mature plant growth stages.

\section{LITERATURE CITED}

Adhikari, T. B., Balaji, B., Breeden, J., and Goodwin, S. B. 2007. Resistance of wheat to Mycosphaerella graminicola involves early and late peaks of gene expression. Physiol. Mol. Plant Pathol. 71:55-68.

Aziz, A., Trotel-Aziz, P., Dhuicq, L., Jeandet, P., Couderchet, M., and Vernet, G. 2006. Chitosan oligomers and copper sulfate induce grapevine defense reactions and resistance to gray mold and downy mildew. Phytopathology 96:1188-1194.

Blée, E. 2002. Impact of phyto-oxylipins in plant defense. Trends Plant Sci. 7: 315-322.

Boyd, L. A., Smith, P. H., Green, R. M., and Brown, J. K. M. 1994. The relationship between the expression of defense-related genes and mildew development in barley. Mol. Plant-Microbe Interact. 7:401-410.

Bradford, M. M. 1976. A rapid and sensitive method for quantitation of microgram quantities of protein utilizing the principle of protein-dye-binding. Anal. Biochem. 72:248-254.

Brading, P. A., Verstappen, E. C. P., Kema, G. H. J., and Brown, J. K. M. 2002. A gene-for-gene relationship between wheat and Mycosphaerella graminicola, the Septoria tritici blotch pathogen. Phytopathology 92:439-445.

Bruce, T. J. 2014. Variation in plant responsiveness to defense elicitors caused by genotype and environment. Plant Physiol. 5:349.

Chartrain, L., Brading, P. A., Widdowson, J. P., and Brown, J. K. M. 2004a. Partial resistance to Septoria tritici blotch (Mycosphaerella graminicola) in wheat cultivars Arina and Riband. Phytopathology 94:497-504.

Conrath, U., Beckers, G. J. M., Flors, V., García-Agustín, P., Jakab, G., Mauch, F., Newman, M.-A., Pieterse, C. M. J., Poinssot, B., Pozo, M. J., et al. 2006. Priming: Getting ready for battle. Mol. Plant-Microbe Interact. 19: 1062-1071. 
Deller, S., Hammond-Kosack, K. E., and Rudd, J. J. 2011. The complex interactions between host immunity and non-biotrophic fungal pathogens of wheat leaves. J. Plant Physiol. 168:63-71.

Desmond, O. J., Manners, J. M., Stephens, A. E., Maclean, D. J., Schenk, P. M., Gardiner, D. M., Munn, A. L., and Kazan, K. 2008. The Fusarium mycotoxin deoxynivalenol elicits hydrogen peroxide production, programmed cell death and defense responses in wheat. Mol. Plant Pathol. 9:435-445.

Diani, Z., El-Mostafa, O., Aissam, S., Hsissou, D., and El-Modafar, C. 2009. Induction of early oxidative events in soft wheat leaves inoculated with Septoria tritici and their relationship to resistance of Moroccan cultivars. Int. J. Agric. Biol. Pak. 11:1560-8530.

Douaiher, M.-N., Nowak, E., Dumortier, V., Durand, R., Reignault, P., and Halama, P. 2007b. Mycosphaerella graminicola produces a range of cell wall-degrading enzyme activities in vitro that vary with the carbon source. Eur. J. Plant Pathol. 117:71-79.

Douaiher, M.-N., Nowak, E., Durand, R., Halama, P., and Reignault, P. 2007a. Correlative analysis of Mycosphaerella graminicola pathogenicity and cell wall-degrading enzymes produced in vitro: The importance of xylanase and polygalacturonase. Plant Pathol. 56:79-86.

Dutsadee, C., and Nunta, C. 2008. Induction of peroxidase, scopoletin, phenolic compounds and resistance in Hevea brasiliensis by elicitin and a novel protein elicitor purified from Phytophthora palmivora. Physiol. Mol. Plant Pathol. 72:179-187.

Eyal, Z. 1999. The Septoria tritici and Stagonospora nodorum blotch diseases of wheat. Eur. J. Plant Pathol. 105:629-641.

Fecht-Christoffers, M. M., Braun, H.-P., Lemaitre-Guillier, C., Van Dorsselaer, A., and Horst, W. J. 2003. Effect of manganese toxicity on the proteome of the leaf apoplast in cowpea. Plant Physiol. 133:1935-1946.

Floerl, S., Majcherczyk, A., Possienke, M., Feussner, K., Tappe, H., Gatz, C., Feussner, I., Kües, U., and Polle, A. 2012. Verticillium longisporum infection affects the leaf apoplastic proteome, metabolome, and cell wall properties in Arabidopsis thaliana. PLoS One 7:e31435.

Goodwin, S. B. 2007. Back to basics and beyond: Increasing the level of resistance to Septoria tritici blotch in wheat. Australas. Plant Pathol. 36: $532-538$

Goodwin, S. B., and Thompson, I. 2011. Development of isogenic lines for resistance to Septoria tritici blotch in wheat. Czech J. Genet. Plant Breed. 47:S98-S101.

Gottwald, S., Samans, B., Lück, S., and Friedt, W. 2012. Jasmonate and ethylene dependent defence gene expression and suppression of fungal virulence factors: two essential mechanisms of Fusarium head blight resistance in wheat? BMC Genomics 13:369.

Govrin, E. M., and Levine, A. 2000. The hypersensitive response facilitates plant infection by the necrotrophic pathogen Botrytis cinerea. Curr. Biol. 10:751-757.

Henry, G., Thonart, P., and Ongena, M. 2012. PAMPs, MAMPs, DAMPs et autres: Mise à jour de la diversité des éliciteurs de l'immunité des plantes. Biotechnol. Agron. Soc. Environ. 16:257-268.

Jones, J. D. G., and Dangl, J. L. 2006. The plant immune system. Nature 444: 323-329.

Kema, G. H. J., Yu, D., Rijkenberg, F. H. J., Shaw, M. W., and Baayen, R. P. 1996. Histology of the pathogenesis of Mycosphaerella graminicola in wheat. Phytopathology 86:777-786.

Kulye, M., Liu, H., Zhang, Y., Zeng, H., Yang, X., and Qiu, D. 2012. Hrip1, a novel protein elicitor from necrotrophic fungus, Alternaria tenuissima, elicits cell death, expression of defence-related genes and systemic acquired resistance in tobacco. Plant Cell Environ. 35:2104-2120.

Lamb, C., and Dixon, R. A. 1997. The oxidative burst in plant disease resistance. Annu. Rev. Plant Physiol. Plant Mol. Biol. 48:251-275.

Li, Y., Huang, F., Lu, Y., Shi, Y., Zhang, M., Fan, J., and Wang, W. 2013. Mechanism of plant-microbe interaction and its utilization in disease-resistance breeding for modern agriculture. Physiol. Mol. Plant Pathol. 83:51-58.

Liang, H., Maynard, C. A., Allen, R. D., and Powell, W. A. 2001. Increased Septoria musiva resistance in transgenic hybrid poplar leaves expressing a wheat oxalate oxidase gene. Plant Mol. Biol. 45:619-629.

Livak, K. J., and Schmittgen, T. D. 2001. Analysis of relative gene expression data using real-time quantitative PCR and the $2^{-\Delta \Delta C T}$ method. Methods 25 : 402-408

Mengiste, T. 2012. Plant immunity to necrotrophs. Annu. Rev. Phytopathol. 50:267-294

Mitchell, H. J., Hall, J. L., and Barber, M. S. 1994. Elicitor-induced cinnamyl alcohol dehydrogenase activity in lignifying wheat (Triticum aestivum L.) leaves. Plant Physiol. 104:551-556.

Mithöfer, A., Schulze, B., and Boland, W. 2004. Biotic and heavy metal stress response in plants: Evidence for common signals. FEBS Lett. 566:1-5.

Nürnberger, T., and Scheel, D. 2001. Signal transmission in the plant immune response. Trends Plant Sci. 6:372-379.

Ors, M., Siah, A., Randoux, B., Selim, S., Boizet, F., Couleaud, G., Maumené, C., Halama, P., and Reignault, P. 2012. Evaluation of plant resistance inducers on different winter soft wheat cultivars against Septoria leaf blotch. Commun. Agric. Appl. Biol. Sci. 77:117-124.

Ors, M. E., Randoux, B., Selim, S., Siah, A., Couleaud, G., Maumené, C., Sahmer, K., Halama, P., and Reignault, P. 2017. Cultivar-dependent partial resistance and associated defence mechanisms in wheat against Zymoseptoria tritici. Plant Pathol. 67:561-572.

Ors, M. E., Randoux, B., Siah, A., Selim, S., Boizet, F., Ade, C., Couleaud, G., Maumené, C., Halama, P., and Reignault, P. 2013. From the lab to the field scale: Dose-dependent efficacy and mode of action of resistance inducers in wheat against Septoria tritici leaf blotch. IOBC WPRS Bull. 89:303-307.

Orton, E. S., Deller, S., and Brown, J. K. M. 2011. Mycosphaerella graminicola: From genomics to disease control. Mol. Plant Pathol. 12:413-424.

Orton, E. S., Rudd, J. J., and Brown, J. K. M. 2017. Early molecular signatures of responses of wheat to Zymoseptoria tritici in compatible and incompatible interactions. Plant Pathol. 66:450-459.

Palmer, C.-L., and Skinner, W. 2002. Mycosphaerella graminicola: Latent infection, crop devastation and genomics. Mol. Plant Pathol. 3:63-70.

Pechanova, O., Hsu, C.-Y., Adams, J. P., Pechan, T., Vandervelde, L., Drnevich, J., Jawdy, S., Adeli, A., Suttle, J. C., Lawrence, A. M., et al. 2010. Apoplast proteome reveals that extracellular matrix contributes to multistress response in poplar. BMC Genomics 11:674.

Peng, M., and Kuc, J. 1992. Peroxidase-generated hydrogen peroxide as a source of antifungal activity in vitro and on tobacco leaf disks. Phytopathology 82:696-699.

Prost, I. 2005. Evaluation of the antimicrobial activities of plant oxylipins supports their involvement in defense against pathogens. Plant Physiol. 139: 1902-1913.

Randoux, B., Renard, D., Nowak, E., Sanssené, J., Courtois, J., Durand, R., and Reignault, P. 2006. Inhibition of Blumeria graminis f. sp. tritici germination and partial enhancement of wheat defenses by Milsana. Phytopathology 96:1278-1286.

Randoux, B., Renard-Merlier, D., Mulard, G., Rossard, S., Duyme, F., Sanssené, J., Courtois, J., Durand, R., and Reignault, P. 2010. Distinct defenses induced in wheat against powdery mildew by acetylated and nonacetylated oligogalacturonides. Phytopathology 100:1352-1363.

Ray, S., Anderson, J. M., Urmeev, F. I., and Goodwin, S. B. 2003. Rapid induction of a protein disulfide isomerase and defense-related genes in wheat in response to the hemibiotrophic fungal pathogen Mycosphaerella graminicola. Plant Mol. Biol. 53:741-754.

Robert-Seilaniantz, A., Navarro, L., Bari, R., and Jones, J. D. G. 2007. Pathological hormone imbalances. Curr. Opin. Plant Biol. 10:372-379.

Samain, E., van Tuinen, D., Jeandet, P., Aussenac, Th., and Selim, S. 2017. Biological control of Septoria leaf blotch and growth promotion in wheat by Paenibacillus sp. strain B2 and Curtobacterium plantarum strain EDS. Biol. Control 114:87-96.

Samain, E., Aussenac, T., and Selim, S. 2019. The effect of plant genotype, growth stage and Mycosphaerella graminicola strains on the efficiency and durability of wheat-induced resistance by Paenibacillus sp. strain B2. Front. Plant Sci. 10:587.

Selim, S. 2016. Zymoseptoria tritici strain 1193 eburicol 14 alpha-demethylase (CYP51) gene, partial cds. National Center for Biotechnology Information, Bethesda, MD. https://www.ncbi.nlm.nih.gov/nuccore/KX356102

Selim, S., Roisin-Fichter, C., Andry, J.-B., and Bogdanow, B. 2011. Accuracy of real-time PCR to study Mycosphaerella graminicola epidemic in wheat: From spore arrival to fungicide efficiency. Pages 219-238 in: Fungicides-Beneficial and Harmful Aspects. N. Thajuddin, ed. InTechOpen. doi:

Selim, S., Roisin-Fichter, C., Andry, J.-B., Bogdanow, B., and Sambou, R. 2014. Real-time PCR to study the effect of timing and persistence of fungicide application and wheat varietal resistance on Mycosphaerella graminicola and its sterol $14 \alpha$-demethylation-inhibitor-resistant genotypes. Pest Manag. Sci. 70:60-69.

Shetty, N. P., Jensen, J. D., Knudsen, A., Finnie, C., Geshi, N., Blennow, A., Collinge, D. B., and Jørgensen, H. J. L. 2009. Effects of $\beta$-1,3-glucan from Septoria tritici on structural defense responses in wheat. J. Exp. Bot. 60: 4287-4300.

Shetty, N. P., Kristensen, B. K., Newman, M.-A., Møller, K., Gregersen, P. L., and Jørgensen, H. J. L. 2003. Association of hydrogen peroxide with restriction of Septoria tritici in resistant wheat. Physiol. Mol. Plant Pathol. 62: 333-346.

Shetty, N. P., Mehrabi, R., Lütken, H., Haldrup, A., Kema, G. H. J., Collinge, D. B., and Jørgensen, H. J. L. 2007. Role of hydrogen peroxide during the interaction between the hemibiotrophic fungal pathogen Septoria tritici and wheat. New Phytol. 174:637-647.

Siah, A., Deweer, C., Duyme, F., Sanssené, J., Durand, R., Halama, P., and Reignault, P. 2010a. Correlation of in planta endo-beta-1,4-xylanase activity with the necrotrophic phase of the hemibiotrophic fungus Mycosphaerella graminicola. Plant Pathol. 59:661-670.

Siah, A., Deweer, C., Morand, E., Reignault, P., and Halama, P. 2010b. Azoxystrobin resistance of French Mycosphaerella graminicola strains 
assessed by four in vitro bioassays and by screening of G143A substitution. Crop Prot. 29:737-743.

Simón, M. R., Cordo, C. A., Castillo, N. S., Struik, P. C., and Börner, A. 2012. Population structure of Mycosphaerella graminicola and location of genes for resistance to the pathogen: Recent advances in Argentina. Int. J. Agron. 2012:e680275.

Tayeh, C., Siah, A., Randoux, B., Halama, P., Walters, D. R., and Reignault, P. 2014. Topical application of inducers for disease control. Pages 193-231 in: Induced Resistance for Plant Defense: A Sustainable Approach to Crop Protection, 2nd ed. D. Walters, A. Newton, and G. Lyon, eds. John Wiley \& Sons, Ltd., Chichester, U.K.

Thakur, M., and Sohal, B. S. 2013. Role of elicitors in inducing resistance in plants against pathogen infection: A review. ISRN Biochem. 2013:1-10.

Tian, S. M., Weinert, J., and Zhao, Q. H. 2009. Correlation between cell walldegrading enzymes in wheat leaves infected by Septoria tritici and disease severity. Can. J. Plant Pathol. 31:387-392.

Underwood, W. 2012. The plant cell wall: A dynamic barrier against pathogen invasion. Front. Plant Sci. 3:85.

Van Loon, L. C., and Van Strien, E. A. 1999. The families of pathogenesisrelated proteins, their activities, and comparative analysis of PR-1 type proteins. Physiol. Mol. Plant Pathol. 55:85-97.

Vavrina, C. S., Roberts, P. D., Kokalis-Burelle, N., and Ontermaa, E. O. 2004. Greenhouse screening of commercial products marketed as systemic resistance and plant growth promotion inducers. HortScience 39:433-437.

Walters, D., Newton, A. C., and Lyon, G. 2008. Induced Resistance for Plant Defense: A Sustainable Approach to Crop Protection. John Wiley \& Sons, New York.

Walters, D., Walsh, D., Newton, A., and Lyon, G. 2005. Induced resistance for plant disease control: maximizing the efficacy of resistance elicitors. Phytopathology 95:1368-1373.
Walters, D. R., Havis, N. D., Paterson, L., Taylor, J., and Walsh, D. J. 2011. Cultivar effects on the expression of induced resistance in spring barley. Plant Dis. 95:595-600.

Wasternack, C. 2007. Jasmonates: An update on biosynthesis, signal transduction and action in plant stress response, growth and development. Ann. Bot. 100:681-697.

Yang, F., Li, W., Derbyshire, M., Larsen, M. R., Rudd, J. J., and Palmisano, G. 2015. Unraveling incompatibility between wheat and the fungal pathogen Zymoseptoria tritici through apoplastic proteomics. BMC Genomics 16: 362.

Yang, F., Li, W., and Jørgensen, H. J. L. 2013b. Transcriptional reprogramming of wheat and the hemibiotrophic pathogen Septoria tritici during two phases of the compatible interaction. PLoS One 8:e81606.

Yang, F., Melo-Braga, M. N., Larsen, M. R., Joergensen, H. J. L., and Palmisano, G. 2013a. Battle through signaling between wheat and the fungal pathogen Septoria tritici revealed by proteomics and phosphoproteomics. Mol. Cell. Proteomics 12:2497-2508.

Yao, Y. N., Wang, J., Ma, X., Lutts, S., Sun, C., Ma, J., Yang, Y., Achal, V., and $\mathrm{Xu}, \mathrm{G} .2012$. Proteomic analysis of $\mathrm{Mn}$-induced resistance to powdery mildew in grapevine. J. Exp. Bot. 63:5155-5170.

Zhang, H., Wu, Q., Cao, S., Zhao, T., Chen, L., Zhuang, P., Zhou, X., and Gao, Z. 2014a. A novel protein elicitor (SsCut) from Sclerotinia sclerotiorum induces multiple defense responses in plants. Plant Mol. Biol. 86:495-511.

Zhang, Y., Yang, X., Liu, Q., Qiu, D., Zhang, Y., Zeng, H., Yuan, J., and Mao, J. 2010. Purification of novel protein elicitor from Botrytis cinerea that induces disease resistance and drought tolerance in plants. Microbiol. Res. 165:142-151.

Zhang, Y., Yang, X., Zeng, H., Guo, L., Yuan, J., and Qiu, D. 2014b. Fungal elicitor protein PebC1 from Botrytis cinerea improves disease resistance in Arabidopsis thaliana. Biotechnol. Lett. 36:1069-1078. 